$1-1-1938$

\title{
Response of permanent pastures to lime and fertilizers (1930 to 1936)
}

\author{
R. R. Robinson
}

W.H. Pierre

Follow this and additional works at: https://researchrepository.wvu.edu/ wv_agricultural_and_forestry_experiment_station_bulletins

\section{Digital Commons Citation}

Robinson, R. R. and Pierre, W. H., "Response of permanent pastures to lime and fertilizers (1930 to 1936)" (1938). West Virginia Agricultural and Forestry Experiment Station Bulletins. 289.

https://researchrepository.wvu.edu/wv_agricultural_and_forestry_experiment_station_bulletins/290 @ WVU. It has been accepted for inclusion in West Virginia Agricultural and Forestry Experiment Station Bulletins by an authorized administrator of The Research Repository @ WVU. For more information, please contact ian.harmon@mail.wvu.edu. 


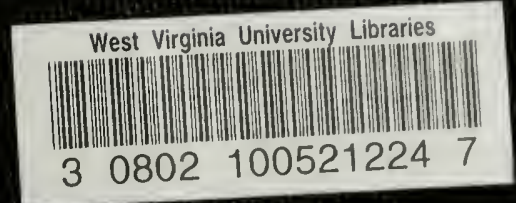





\title{
Response of Permanent Pastures to Lime and Fertilizers [1930 to 1936]
}

\author{
R. R. ROBINSON
}

Division of Forage Crops and Diseases, Bureau of Plant Industry, U. S. D. A. W. H. PIERRE

West Virginia Agricultural Experiment Station

West Virginia Agricultural Experiment Station, Morgantown C. R. Orton, Director

In Cooperation with the Bureau of Plant Industry of the United States Department of Agriculture 


\section{Agriculteril Expermant Station Stap}

C. S. BOL'CHER, Ph. D., I.L. D., President of the Liniversity

C. R. ORTON, Ph. D. ................. Dean and Director JUHN C. JOHNSTON, Chief Cherk ... GERALD JENNY, M. S., Agricultural Editor

\section{AGRONOMY AND GENETICS}

G. G. Pohlman, Ph. D., IJead of Dept.

WV. M. Brondfoot, M. S., Asst, in Agron.

C. R. Burnham, Ph. D.,* Assoc. Gen.

J. 1. Cartledge, Ph. D., Asst. Gen.

Euna Davis, A. B., Asst. in Agron.

T. C. MeIlvaine, Ph. D., $* \dagger$ Assoc. Agron.

J. A. Pigney, M. S., Asst. in Agron.

E. H. Tyner, Ph. D., Asst. Agron.

\section{ANIMAL HESB.INDRY}

E. A. Livesay, D. Sc., Heitd of Dept.

M. L. Buchanan, M. S., Asst. in An. Husb.

T. B. Clark, M. S., Asst. Poult. IIusb.

J. H. Longwell, A. M., Asst. An. Husb.

E. N. Moore, D. V. M., Asst. An. Patl.

J. H. Rietz, D. V. M., An. Patl.

E. T. Wightman, M. S., Asst. Poult. Husb.

C. T. Wilson, M. S., Assoc. An. IJusb.

\section{CHEMISTRY}

F. B. Dustman, Ph. D., Head of Dept.

I. J. Duncan, Ph. D., Asst. Chem.

A. H. VanLandingham, Ph. D., Asst. Chem.

C. E. Weakley, Jr., M. A., Assoc. Chem.

\section{DAIRY HI'SBANDRY}

II. O. Henderson. Pli. D., IIead of Dept.

R. A. Ackerman, M. S., Asst. Dairy Husb.

G. A. Eowling, M. S.. Assoc. Dairy Husb.

IV. C. Brown, Ph. D., Asst, in Dairy Husb.

I. J. Manus, M. S., Asst. in Dairy Husb.

\section{PNTOMOLOGY}

L. M. Peairs, Ph. D., Head of Dept.

Edwin Gould, B. S., ${ }^{*} \dagger \dagger$ Assor. Ent.

\section{[FTONOMICS}

IV. Wr. Armentrout, Ph. D., Head of [inelit.

MI. A. Abrahamsen, M. A., Asst. Agr. Econ.

F. D. Cornell, Jl., Ph. D., Assoc. Agr. Econ.

Margaret Cross, B. S. H. E., Statistician

W. K. Lanham, 3. S. Agr., Asst, in Agr. Econ.

E. O. Leonard, B. S. Agr., Asst. in Agr. Eeon.

Gertrude Lucas, A. B., Statistician

L. F. Herrmann, M. S., Asst. in Agr. Econ.

E. C. Weitzell, M. S.,* Asst. Agr. Econ.

\section{FORESTRY}

Ii. C. Fercival, Ph. D., Head of Dept. I. Besley, M. F., Assoc. For.

11. D. Erickson, Pl. D., Asst. For.

L. E. Lutz, Researeh isst.

\section{HORTICULTURE}

R. S. Marsh, A. M., Head of Dept. E. P. Brasher, M. S., Asst. in Hort. II. H. Childs, M. S., Asst. in Hort. WV. H. Duis, M. S., Asst. in Hort. A. P. Dye, M. S. Agr., Asst. in Hort. R. TI. Sudds, Ph. D., Asst. Hort. I. C. Westover, Ph. D., Assoc. Hort

\section{PL. INT PATHOLOGY}

C. R. Orton, Ph. D., Head of Dept. Anthony Bers, M. S., Assoc. Plant Path.

Hazel C. Cameron, M. A., Assor. Physiol.

Genevieve B. Clulo, M. A., Asst, in Plant Path.

I. M. Hill, M. S., Asst. in Plint Path.

L. H. Leonian, Ph. D., Mycol.

V. G. Lilly, Ph. D., Asst. Physiol.

E. A. Marten, Ph. D., Asst. Bact.

C. F. Taylor, Ph. D., Asst, Plant Path.

*In cooperation with the U. S. Department of Agriculture, Washington, D. C.

in charge of the Lakin Experiment Farm, Lakin, W. Va.

In charge of the Feymann Memorial Farms, Wardensville, W. Va.

$\dagger$ In charge of the University Experiment Farm, Kearneysville, W. Va. 


\title{
Response of Permanent Pastures to Lime and Fertilizers (1930 to 1936)"
}

\author{
by R. R. ROBINSON and W. H. PIERRE:
}

\section{INTRODUCTION}

The importance of permanent pastures in West Virginia agricnlture arises from two general facts, namely: (1) pastures fumish the (heapest feed produced on the fartil, and (2) pastures protect the soil from erosion and provide the best land-use possible on a large poportion of the farm land. According to the 1935 census, permanent pastures constitute 62 percent of the cleared farm land in the state. Yot no other important erop has been so neglected in this state.

The extent to which permanent pastures hae been neglected in West Virginia is well shown by a recent study of 775 representative pastures situated in different sections of the state. $(\%) *$ In over 50 percent of the pasture area studied at least fire acres were needed to pasture one 1000-pound animal, and only about 10 percent of the area was able to support an animal on two acres or less. Kentucky bluegrass, white clover, and other desirable pasture plants were found to average less than one-fourth of a stand, whereas weeds averaged 20 percent, poor native grasses 30 percent, and bare space 25 percent.

Imporerished soil is the main reason for the poor type of regetation and the low carrying capacity of many West Virginia pastures $(\%, 9)$. By the use of lime and fertilizers it has been found that the productivity of permanent pastures can be greatly increased (j). Many questions still remain however, regarding the response to lime and fertilizers that may be expected on different soil types and on soils impoverished to various extents by erosion, by grazing, and by previous eropping. Moreover, relatively little is known about the residual effect from fertilizers and lime. Soil fertility experiments with pastures are more difficult and more expensive to conduct than similar experiments

†The investigations herein reported were conducted in cooperation with the Division of Forage Crops and Diseases, Bureau of Plant Industry, U. S. Department of Agriculture.

tAssociate Agronomist, Division of Forage Crops and Diseases, United States Department of Agriculture, and formerly head of Department of Agronomy and Genetics, respeetively. The authors wish to acknowledge the assistance during 1935 and 1936 of W. K. Lanham, formerly graduate assistant. The cooperation and assistance of Joseph P. Kuykendall, Ivan Mckeever. B. I. Speicher, and others of the Soil Conservation Service in the investigation at Spencer and Palestine are gratefully acknowledged.

Reference by number is to Literature Cited, p. 46. 
with most general farm crops, and relatively few experiments are available to show what may be expected over a period of years from proper pasture treatment and management.

In order to get some additional information on this problem, the present study was undertaken in 1930 in cooperation with the Burean of Plant Industry of the United States Department of Agriculture. The main objectives of the experiments were as follow:

(1) To compare the response of permanent pastures on different soil types to rarious lime and fertilizer treatments, as measured by

(a) Changes in the botanical composition of the vegetation.

(b) Yield of forage.

(c) Chemical composition of the forage.

(2) To study the relationship between the chemical composition of the soil and the response of pastures to lime and fertilizer treatments.

(3) To determine the residual effect of these treatments over a period of years and to study the downward movement of lime and phosphorus into the soil.

These experiments represent a total of 516 small plots located on seven soil types in different sections of the state. In addition, an experiment involving the use of plots of $4 \frac{1}{2}$ to 6 acres each was established in one of the experimental areas in cooperation with the Department of Dairy Husbandry for the purpose of comparing the increases in vields measured by grazing with those obtained by clipping. The results of the grazing experiment will be only briefly referred to in this publication but will be reported in more detailed form in another bulletin of the Agricultural Experiment Station.

\section{PLAN AND DESCRIPTION OF THE EXPERIMENTS}

The experiments were conducted on permanent pastures situated in various parts of the state in order to obtain a better knowledge of the effect of fertilizer and lime treatments on different soils and under various climatic conditions. Table 1 shows the location of the experimental areas, the dates the experiments were started, the soil type, depth of surface soil, and certain chemical properties of the soil. The Dekalb soils, which are derived from non-calcareous shales and from sandstones, are considered to be among the least productive of the upland soils, yet they will produce very good crops if limed, fertilized, and properly managed. The Upshur and the Westmoreland soils are derived partly from calcareous materials and are somewhat more productive than the Dekalb. The Huntington is a fertile bottomland soil derived from the wash of limestone uplands. The Monongahela and Holston are terrace soils derived from non-calcareous material. None of the areas selected for the experiments is found on slopes of more than about. 15 percent. Erosion had removed ronsiderable amounts of topsoil, and 


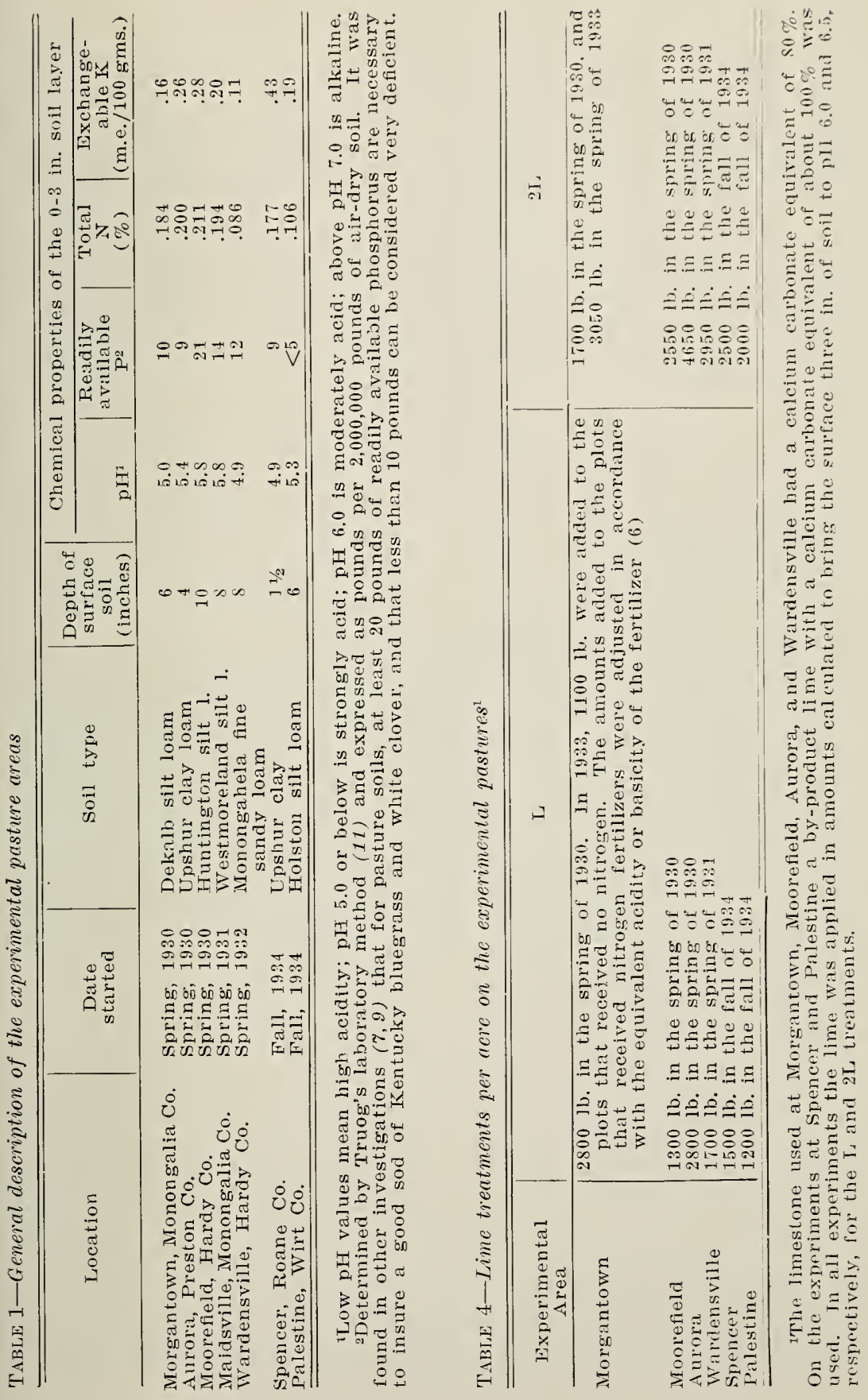




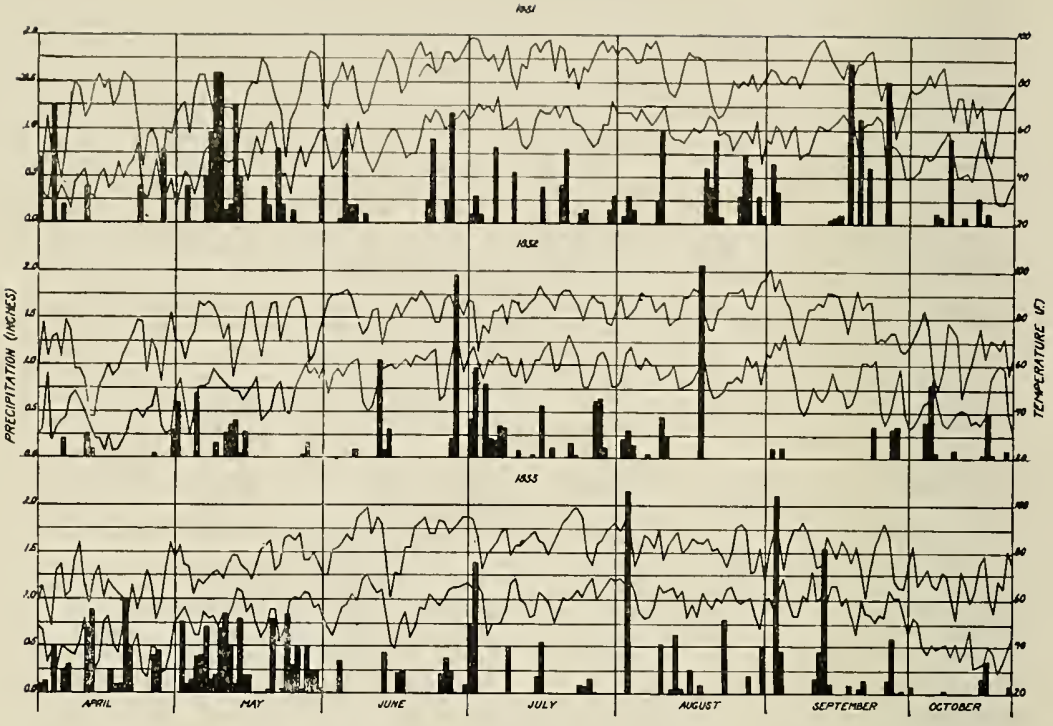

19v

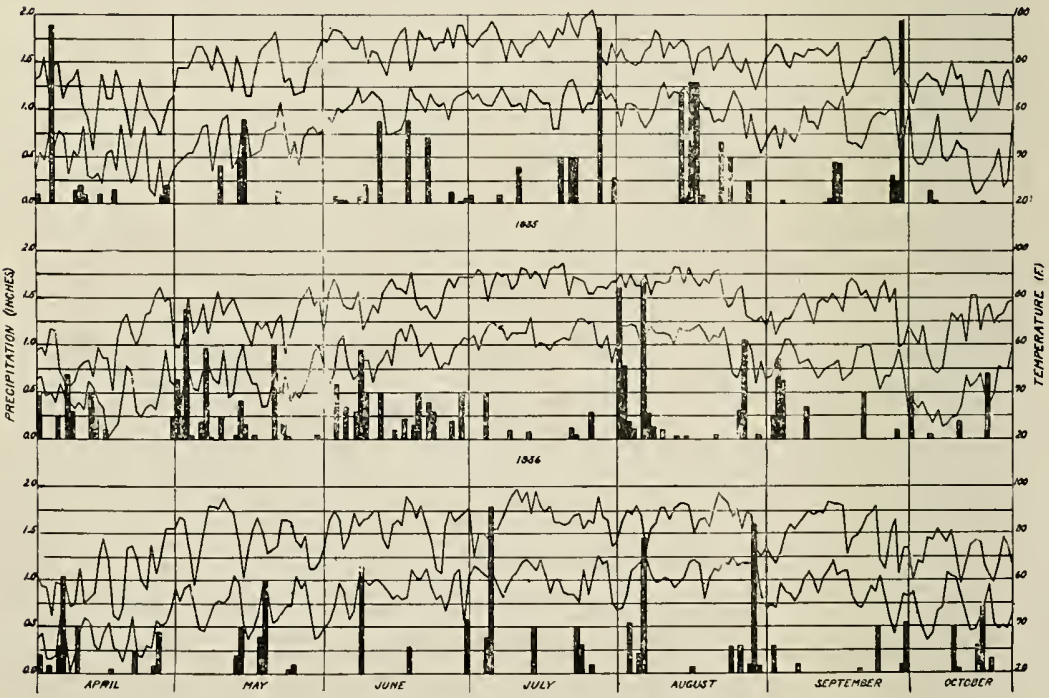

Fic. 1-Rainfall and temperature data for Morgantown area (1931-1936)*

*The rainfall data were obtained mostly from the Federal weather Bureau station at Morgantown. Where the records at Morgantown are not complete the data were obtained fron the nearby Faimont station. The temperature data were ob:ained from the station at Clarksburg rather than at Morgantown because the records are more complete and the data obiously more trustworthy. 
the Upshur elay soil at Speneer is seve"ely eroded. As shown in the table, this area has only $1 \frac{1}{2}$ in. of topsoil. All of the soils are moderately to strongly acid and low to very low in available phosphorus as measured by Truog's method (11). Thu'ee of the areas are very low in nitrogen and organie matter. The eleration of the experimental areas is approximately $1000 \mathrm{ft}$, except at Auroral, where it is $2500 \mathrm{ft}$., aud at Speneer and Palestine, where it is abont $700 \mathrm{ft}$.

The average annual precipitation for West Virginia is 43 in. At Aurora the precipitation is abont $10 \mathrm{in}$. higher than the average for the state, whereas at Moorefield and Wardensville it is about 10 in. lower. The total rainfall during the six summer mouths ( $\Lambda$ pril to September) averages about 55 pereent of the total for the year, and the months of greatest precipitation are usually June, July, and $A$ ugust. In spite of the higher rainfall the pastures are usually drier during July and August than at any other time during the year. This, of course, is due to the high temperatures, which result in rapid evaporation and transpiration.

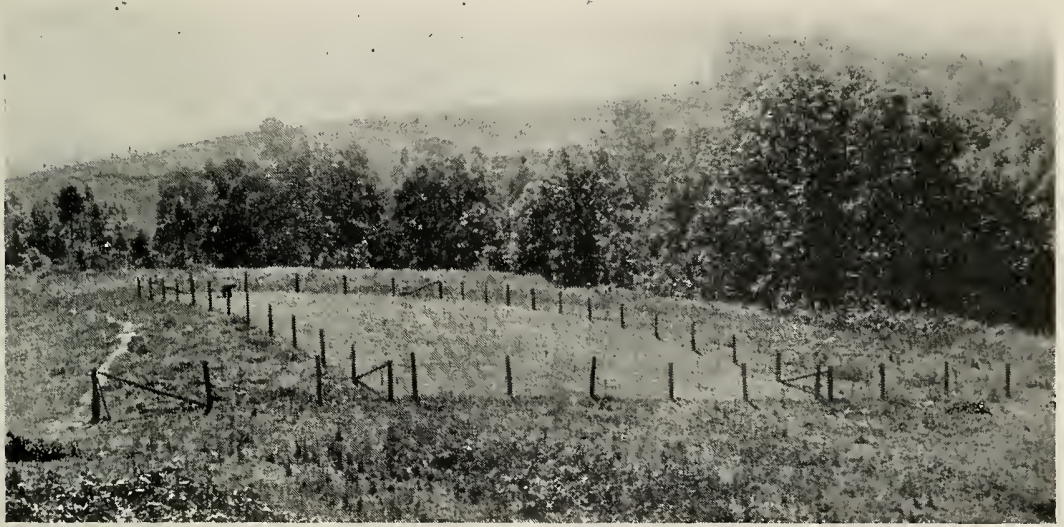

FIG. 2-Photograph of the Spencer plots, situatel on a poor pastue area of Upshur elay

During the period in which these experiments were in progress, weather eonditions were less favorable than normal. The summers of 1930, 1934, and 1936 were relatively dry and poor for pasture produetion. The seasons of 1932 and 1935 were fair, and only the seasons of 1931 and 1933 were very favorable. These facts should be considered when interpreting the results. Rainfall and temperature data for the Morgantown station for 1931-1936 inclusive are given in Figure 1.

Each of the experimental areas was divided into a number of 0.002 acre plots $(71 / 4 \times 12 \mathrm{ft}$.) which were separated by narrow allers [Figure $2]$. The important combinations of lime and fertilizers for the experiments started in 1930 and in 1932 are shown in Table 2, and those for the experiments started in 1934, in Table 3. The other treatments in- 
TABLE - Description of some of the important treatments of the four main extperiments (Horgantown. Lwora, Mooreficld, and Hardensville) ${ }^{1}$

\begin{tabular}{|c|c|c|}
\hline $\begin{array}{l}\text { Treatment } \\
\text { No. }\end{array}$ & $\begin{array}{l}\text { Treatment } \\
\text { designation }\end{array}$ & Description of treatment ${ }^{3}$ \\
\hline $3, s, 13$ & Check & None \\
\hline 10 & $2 \mathrm{~L}$ & Lime \\
\hline 1 & $\mathrm{P}$ & Superphospliate \\
\hline 2 & P-2L & Superphosphate and lime \\
\hline 1 & $\mathrm{P}-\mathrm{is}$ & Superphosphate and muriate of potash \\
\hline$\therefore$ & P-K-2L & Superphosphate, muriate of potash, and lime \\
\hline 6 & $\mathrm{~N}-\mathrm{P}-\mathrm{I}$ & $\begin{array}{l}\text { Nitrate of soda, superphosphate, and muriate of } \\
\text { potash }\end{array}$ \\
\hline 氵 & N-P-K-2L, & $\begin{array}{l}\text { Nitrate of soda, superplospliate, muriate of potash, } \\
\text { and lime }\end{array}$ \\
\hline$!$ & $\mathrm{N}-\mathrm{P}-\mathrm{K}-\mathrm{L}$ & Same as No. 7 , except different amounts of lime \\
\hline 11 & $1 / 2 N-P-I-2 L$ & $\begin{array}{l}\text { Same as No. } 7 \text {, except one-half as much nitrate of } \\
\text { soda }\end{array}$ \\
\hline 12 & $2 N-\Gamma-T i-2 L$ & $\begin{array}{l}\text { Same as No. } 7 \text {, except twice as inuch nitrate of } \\
\text { soda }\end{array}$ \\
\hline 14 & $2 \mathrm{~N}-2 \mathrm{P}-\mathrm{I}-2 \mathrm{~L}$ & $\begin{array}{l}\text { Same as No. T, except twice as much nitrate of } \\
\text { soda and superphosphate }\end{array}$ \\
\hline 15 & $\mathrm{~N}-2 \mathrm{P}-\mathrm{I}-2 \mathrm{I}$ & Same as No. 7, except twice as nuch superphosphate \\
\hline
\end{tabular}

${ }^{1}$ Tables 5 and 15 give the additional treatments at Morgantown and Wardensville respectively; and Table 8 for the treatinents at Maidsville.

${ }^{2}$ In the Morgantown experiment $2 \mathrm{~L}$ was substituted for $\mathrm{L}$ in treatment No. 9, and $\mathrm{L}$ for $2 \mathrm{~L}$ in the other plots receiving lime. See Table 4 for the amounts of lime used in the different experiments.

${ }^{3}$ Amounts used: (1b. per acre)

$\mathrm{P}=500$ lb. $20 \%$ superphosphate in first and third years of experiment.

$2 \mathrm{P}=5001 \mathrm{~b} .20 \%$ superphosphate in each of first four years.

$\mathrm{K}=100 \mathrm{lb}$. muriate of potash in first and third years.

$1 / 2 \mathrm{~N}=100 \mathrm{lb}$. nitrate of soda in early spring.

$\mathrm{N}=100$ lb. nitrate of soda in early spring and in midsummer.

$2 \mathrm{~N}=200$ lb. nitrate of soda ir early spring and in midsummer.

cluded in the Morgantown and Wardensville experiments and the special nitrogen treatments of the Haidsville experiment are shown in connection with the tables on yield and botanical composition. Table $t$ (see page 5) shows the amounts of lime used in the various experiments. All treatments were in quadruplieate. Except for the area at Wardensville, which was plowed and reseeded, lime and fertilizer were applied as a topdressing without seed or cultural treatment.

Yields of forage were determined by elipping the plots with a lawnmower. The frequency of elipping depended upon the rate of growth, but ordinarily four to six elippings were made during a season. At Spencer and Palestine the herbage was elipped at a height of approximately one inch. The other areas were elipped at a height of $11 / 4$ in. during the first three year's ; since then they have been clipped at a height of 2 in. The clipped herbage was dried at a temperature of approximately $150^{\circ} \mathrm{F}$. and the vields expressed as pounds per aere of dry forage (about $11 / 2 \%$ moisture). The clippings from eertain sclected plots were analyzed for ealeium, phosphorus, and erude protein.

In addition to determining the yields and the chemical eomposition of the forage, estimates of the botanical emposition of each plot were made usually twice each year, during June and September. 'These esti- 
mates give the percentage of the total area occupied by bare sparer, weeds, legumes, desirable pasture grasses, and undesirablo native grasses. Forty percent Kentucky blueglass, for rample, moans 40 percent of a perfect stand of Kentucky blucerass. T'en percent bare sparee means that the total vegetation makes up 90 pereent of a perferet stand.

TABLE 3-Deseription of fertilizer treatmen!s of Speneer and Palestine experiments'

\begin{tabular}{|c|c|c|}
\hline $\begin{array}{l}\text { Treatment } \\
\text { No. }\end{array}$ & $\begin{array}{l}\text { Treatment } \\
\text { designation }\end{array}$ & Description of tratment ${ }^{2}$ \\
\hline $3, \&$ & Check & None \\
\hline 1 & $\mathrm{P}$ & Superphosphate \\
\hline 2 & P.L & Superphosphate and lime \\
\hline 4 & $\mathrm{P}-\mathrm{K}$ & Superphosphate anrl muriate of potash \\
\hline 5 & $\mathrm{P}-\mathrm{K}-\mathrm{I}$ & Superphosphate, muriate of potash, and lime \\
\hline 6 & N-P.K & $\begin{array}{l}\text { Sulfite of ammonia, superphosphate, and mitiate } \\
\text { of potash }\end{array}$ \\
\hline$\vec{\imath}$ & $\mathrm{N}-\mathrm{P}-\mathrm{K}-\mathrm{L}$ & $\begin{array}{l}\text { Sulfate of ammonia, superphosphate, muriate of } \\
\text { potash, and lime }\end{array}$ \\
\hline 9 & $\mathrm{~N}-\mathrm{P}-\mathrm{T}-21$ & Sane as No. 7 , except for arditional lime \\
\hline 10 & [1 & Lime \\
\hline 12 & $\mathrm{~N}-\mathrm{P}-\mathrm{I}$ & $\begin{array}{l}\text { Same as No. 7, except that muriate of potash is } \\
\text { omitted }\end{array}$ \\
\hline 13 & $1 / 2 \mathrm{~F}-\mathrm{I}$ & $\begin{array}{l}\text { Same as No, } 2 \text {, except that amount of superpliosphate } \\
\text { is reduced }\end{array}$ \\
\hline 14 & $1 / 2 \mathrm{P}-1 / 2 \mathrm{~K}-\mathrm{L}$ & $\begin{array}{l}\text { Sanie as No. } 5 \text {, except that amounts of superphosphate } \\
\text { and moniate of potash are reduced }\end{array}$ \\
\hline
\end{tabular}

${ }^{1}$ See Table $4 \mathrm{fcr}$ amounts of lime used.

2 Amounts of fertilizer used are as follows:

$P=500 \mathrm{lb} .20 \%$ superphosphate in fail of 1934.

$1 / 2 \mathrm{P}=300 \mathrm{lb}, 20 \%$ superphosphate in fall of 1934 .

$\mathrm{K}=100 \mathrm{lb}$. muriate of potash in fall of 1934

$1 / 2 \mathrm{~K}=50 \mathrm{lb}$. muriate of potash in fall of 1931 .

$\mathrm{N}=100 \mathrm{lb}$. sulfate of ammonia each sprins.

\section{EFFECT OF LIME AND FERTILIZER ON THE BOTANICAL COMPOSITION OF PASTURES}

It has been found that under West Virginia conditions 'he botanical composition of a pasture is a good measure of its productivity ( 1 ). If the soil is fertile Kentucky bluegrass (Poa pratensis) and white clover (Trifolium repens) are the dominant species unless of course the pasture has been grossly mismanaged. Other desirable plant species found in West Virginia pastures are: red top (Agrostis alba), timothy (Phleum pratense), Canada bluegrass (Poa compressa), orchard grass (Dactylis glomerata), hop clover (Trifolium spp.), and common lespedeza (Lespedeza striata).

Pastures consisting mostly of these plant species produce not only a greater amount of herbage per acre than does the poor type of pastures, which eontain mostly poverty grass, broomsedge, and weeds; they also produee herbage of better quality. For these reasons it is evident that one of the most praetical methods of determining the value of lime and fertilizers on permanent pastures is to determine the effect of such treatments on the botanical composition of the sod. 


\section{MORGANTOWN EXPERIMENT}

At the time the experiment was started, this area was estimated to contain 58 percent native grasses, largely poverty grass with small percentage of broomsedge; 19 pereent weeds, predominantly cinquefoil. rarrow, everlasting, and English plantain; 7 percent bare space; 2 percent white and red clovers; and 14 percent Kentucky bluegrass and reel top. The small percentage of desirable grasses and legumes in this pasture is not surprising because, as shown in Table 1 , the soil is strongly acid and very low in available phosphorus.

It is evident from Figures $3 \mathrm{a}$ and $3 \mathrm{~b}$ that the lime and fertilizer treatment resulted in a very good sod of Kentucky bluegrass and white clover. White clover came in much sooner than did Kentucky bluegrass, but, as would be expected, it showed marked seasonal variations. The largest amounts were present during 1932 and 1933, although there were also considerable amounts in the late fall of 1931 and the early spring of 1934 on the well-treated plots. The botanical estimates for the P-K-L treatment showed 15 percent clover in 1931 and 35 percent in the fall of 1933. There were only negligible amounts of white clover in 1930 and 1936 and also during most of 1935. Undoubtedly the small percentage of clover on the area during the last few year's was due partly to the unfavorable seasons, 1934 and 1936 being especially dry.

The rate at which the percentage of Kentucky bluegrass increased as a result of lime and fertilizer treatments is shown in Figure 4. It is interesting to note that before clover became an important factor, the P-K-L treatment produced no increase in the percentage of Kentucky bluegrass. Nitrogen fertilizers, in addition to P-K-L, however, mate-

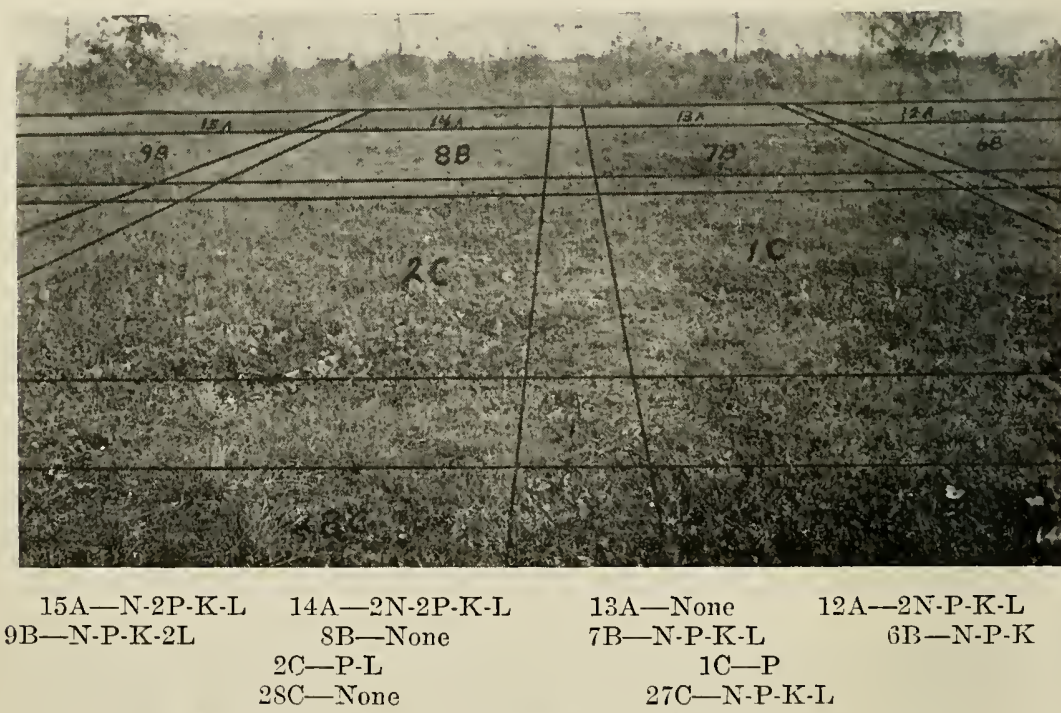

Fig. 3A-Some of the plots on the Dekalb soil at Morgantown, October 9, 1933 


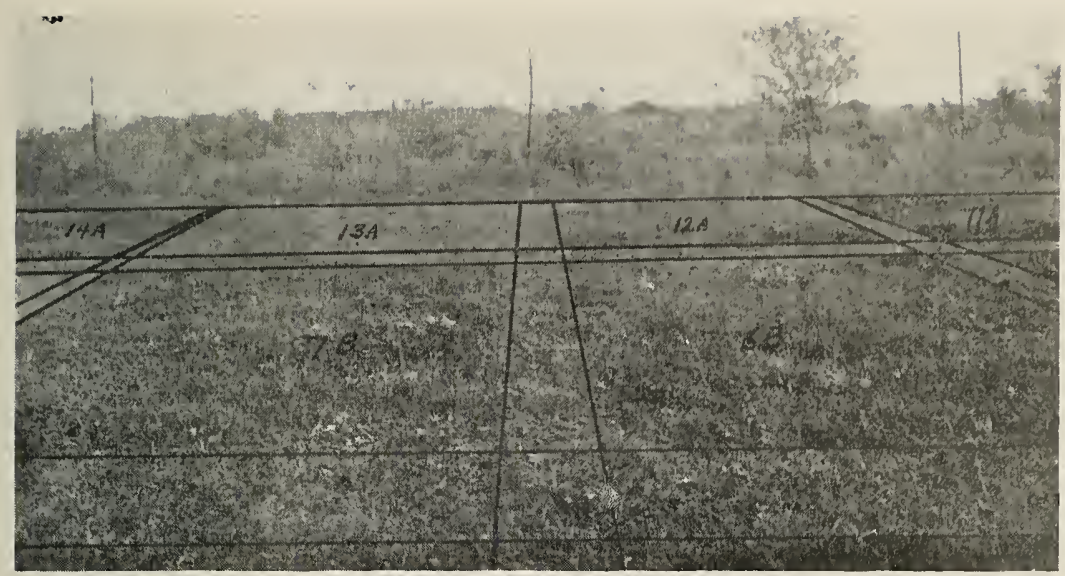
$14 \mathrm{~A}-2 \mathrm{~N}-2 \mathrm{P}-\mathrm{K}-\mathrm{I}$
$13 \mathrm{~A}-$ None $12 \mathrm{~A}-2 \mathrm{~N}-\mathrm{P}-\mathrm{K} \cdot \mathrm{L}$
$6 \mathrm{~B}-\mathrm{N}-\mathrm{P}-\mathrm{K}$
$7 \mathrm{~B}-\mathrm{N}-\mathrm{P}-\mathrm{K}-\mathrm{L}$

Fig. 3B-Some of the plots on the Dekalb soil at Morgantown, October 9, 1933 rially increased the percentage of Kentucky bluegrass during the first year. Following the appearance of large amounts of clover in the fall of 1931 and 1932 there were rapid increases in the percentage of bluegrass; and during the last few years, when the seasons were unfavorable and the amounts of clover very small, marked decreases in the percentage of Kentucky bluegrass were noted, especially on the plots receiving

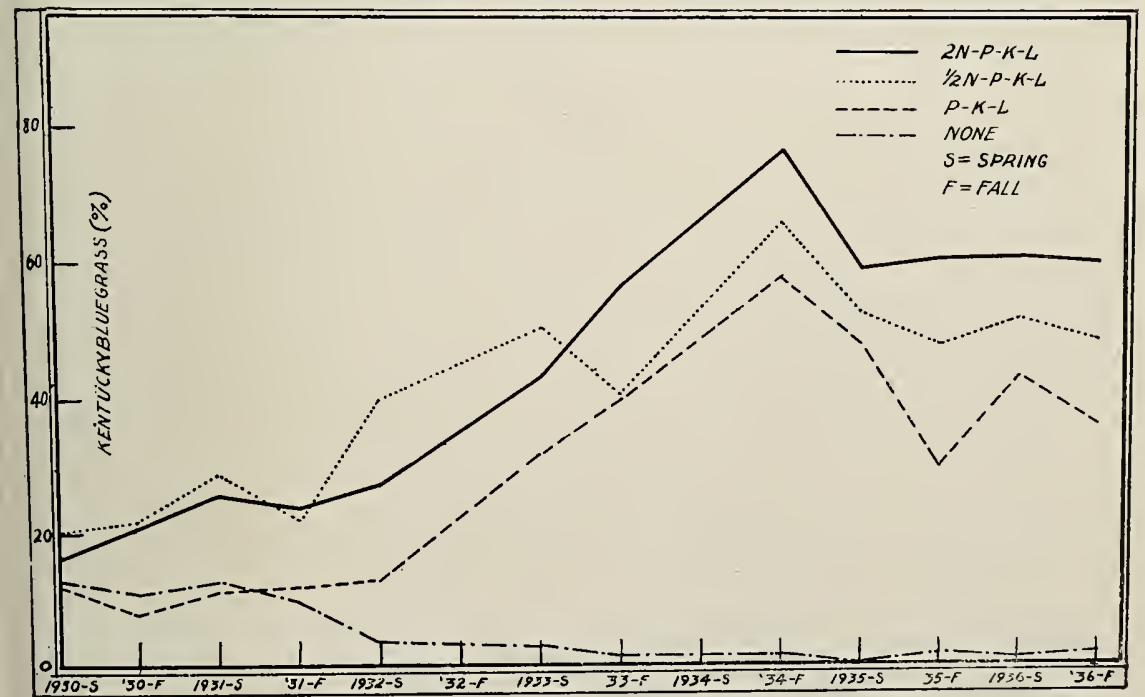

FIG.4 ESTIMATED PERCENTAGES OF KENTUCKY BLUEGRASS [INGLUDES ALSO A SMALL PERGENTAGE OF RED TOH] ON CERTAIN PLOTS ON THE DEKALB SILT LOAM AT MORGANTOWN. 


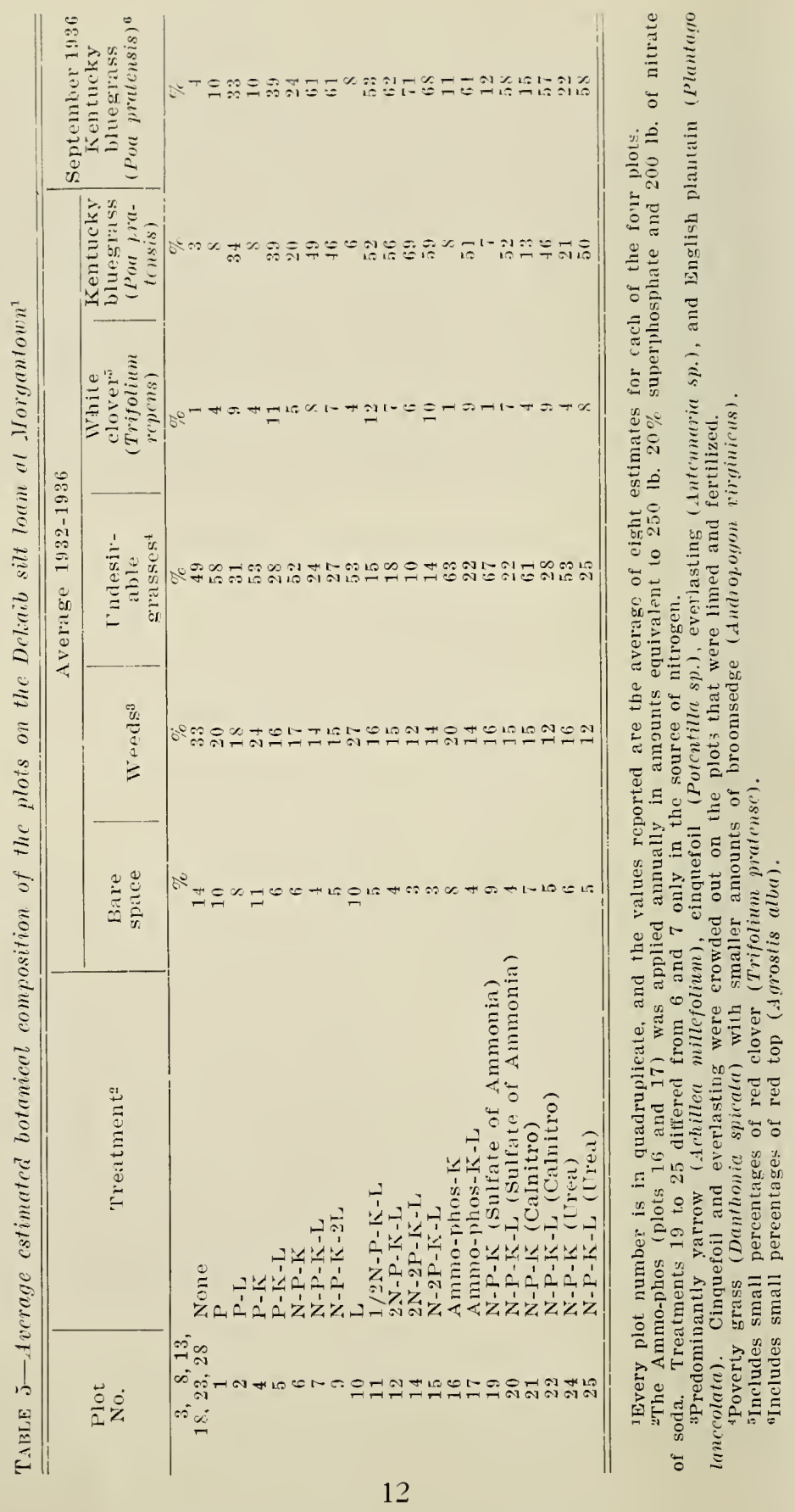


no nitrogen fertilizer. It should be recognized, howerer, that the efferet of the absence of clover on the pereentage of bluegrass would show up much more quiekly on these plots than on grazed plots since the latter reeeive a considerable amount of nitrogen from manwe.

The average values of eight botanical estimates during the period 1932-1936 are summarized in 'Table 5. (The first two youl's were onlitied in this summary table because the differences between the varous truatments were still relatively small.) The untreated plots averaged only 4 percent total desirable speeics during this period. lime alone or superphosphate alone had relatively little effect on the rercentage of total desirable species. A combination of lime and superphosphate, however, produced a marked change in the botanical composition of the pasture in that Kentucky bluegrass and white clover replaced a larege percentage of the weeds and undesirable grasses. The average percentage of total desirable species for the P-I treatment was 43. Potash and nitrogen fertilizers, in addition to lime and superphosphate, rave adritional increases in the percentage of total desirable species, the totals for the P-K-L, 1/2N-P-K-L, N-P-K-L, 2N-P-K-L, and 2N-2P-K-L treatments being 50,64, 57, 63, and 75 percent, respectively. Except when used in small amounts, however, nitrogen fertilizer decreased the percentage of clover.

On the limed plots receiving different nitrogen fertilizers, no significant differenee was noted in the pereentage of total desirable species. On the unlimed plots, however, there were very marked differences. The plots receiving non-acid-forming carriers of nitrogen (Calnitro and nitrate of soda) averaged 21 percent total desirable speeies as compared with only 8 percent for those receiving strongly acid-forming carriers (sulphate of ammonia and Ammo-phos). 'The plots that received urea, which is only slightly acid-forming, averaged 25 percent total desilable species.

The percentages of Kentucky bluegrass as estimated in the fall of 1936 are also shown in Table 5 for comparison with the average for 1932 1936. Tery little difference is seen between the two sets of values. This should not be taken to mean that there has been no change in botanical composition, since as shown in Figure 3 , the percentage values for bluegrass increased to a maximum in 1934 and then decreased slightly. The results do show, however, that the cffect of the lime and fertilizer treatments is still very apparent even where no treatment has been given for $41 / 2$ years.

\section{Aurora Experiment}

The average values for the estimated botanical composition of the plots at Aurora during the period 1931-1936 are given in Table 6. Superphosphate alone reduced the bare space from $2+$ to 9 percent and increased the amount of desirable grasses and clover from 7 to 32 percent. Moreover, the very heavy superphosphate treatment was somewhat more effective than the normal application. This marked response 


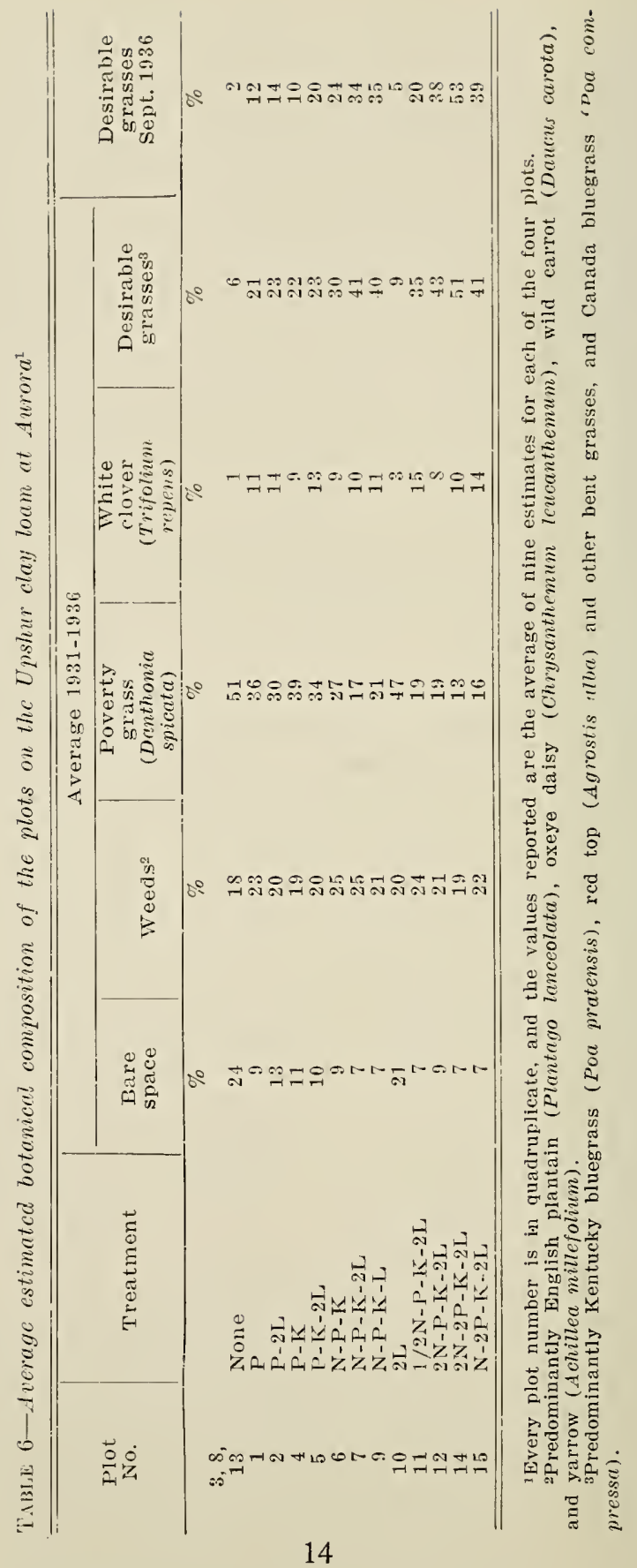




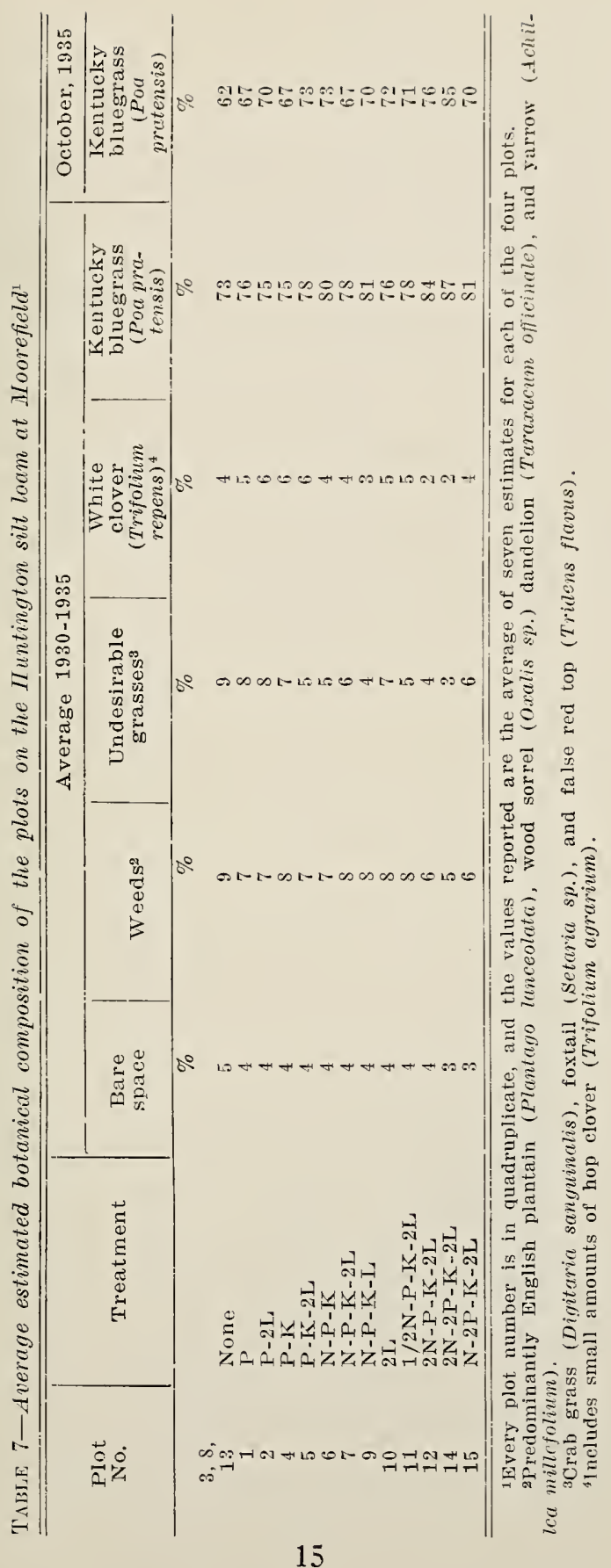


to superphosphate is to be expected heanuse, as shown in Table 1 , the soil is rery low in readily available phospherus. Lime produced only a small increase in the pereentage of desirable species in spite of the fact that the soil has a pH value of 5.4. Potash had no apparent effect on the botanical composition. Ileary applications of nitrogen fertilizer produced a marked increase in the porcentage of desirible grasses but lecreased the percentage of clover. 'The light application of nitrogen, on the other hand, produced a malked increase in the percentage of desirable grasses without decreasing the percentage of white clover. The average percentage of desirable grasses and legumes for the P-K-2L, 1/2N-P-K-2L, N-P-K-2L, and 2N-P-K-2I, treatments was 36, 50, 51, and 51 , respectively. The $2 \mathrm{~N}-2 \mathrm{P}-\mathrm{K}-2 \mathrm{~L}$ treatment increased the total desirable species to 61 percent. Except on the plots receiving heary applications of fertilizer, the percentage of desirable grasses was somewhat lower in 1936 than the average for the period 1931-1936.

As on the Dekalb soil at Morgantown, white clover was much more abundant in 1932 and 1933 than during the other years. There was also a fairly good stand of clover on the treated plots in the fall of 19:31, in the early spring of 1934, and during part of 1935. In 1930 and 1936 the amounts of white clover were negligible.

\section{Moorefield ExpertaleNT}

There was a good sod of Kentucky bluegrass even on the untreated plots on the Huntington silt loam at Moorefield (Table 7). This indicates that neither soil acidity nor soil fertility was an important limiting factor. As shown in Table 1, the untreated soil has a $\mathrm{pH}$ value of 5.8 and has 21 pounds of readily available phosphorus per two million pounds of the $0-3 \mathrm{in}$. layer. It is not surprising. therefore, that lime and fertilizer had relatively little effect on the average botanical composition. The infertilized plots averaged 77 percent desirable grasses and legumes as compared with 89 percent for the very heavily fertilized plots. There was very little clover except in the fall of 1932, during the very favorable year of 1933, and in the early spring of 1934 . For this reason the average values given in Table $T$ appear low and do not adequately show the differences resulting from some of the treatments. For example, the percentage of clover during 1933 for some of the more important plots averaged as follows: untreated, 11 percent; 2L, 22 percent; $\mathrm{P}, 22$ percent; $\mathrm{P}-2 \mathrm{~L}, 30$ percent; $\mathrm{P}-\mathrm{K}-2 \mathrm{~L}$, 30 percent; 1/2N-P-K-L, 23 percent; N-P-K-2L, 13 percent; and 2N-P-K-L, 7 percent. These results show that on a good sod of Kentucky bluegrass cren light applications of nitrogen fertilizer may produce a marked decrease in the percentage of clover.

\section{MLaidsville Experiment}

The Westmoreland soil of this expuriment was neither as strongly acid nor as low in arailable phosphorus as the soils of most of the other areas, and there was a fairly good sod of Kentucky bluegrass at the 


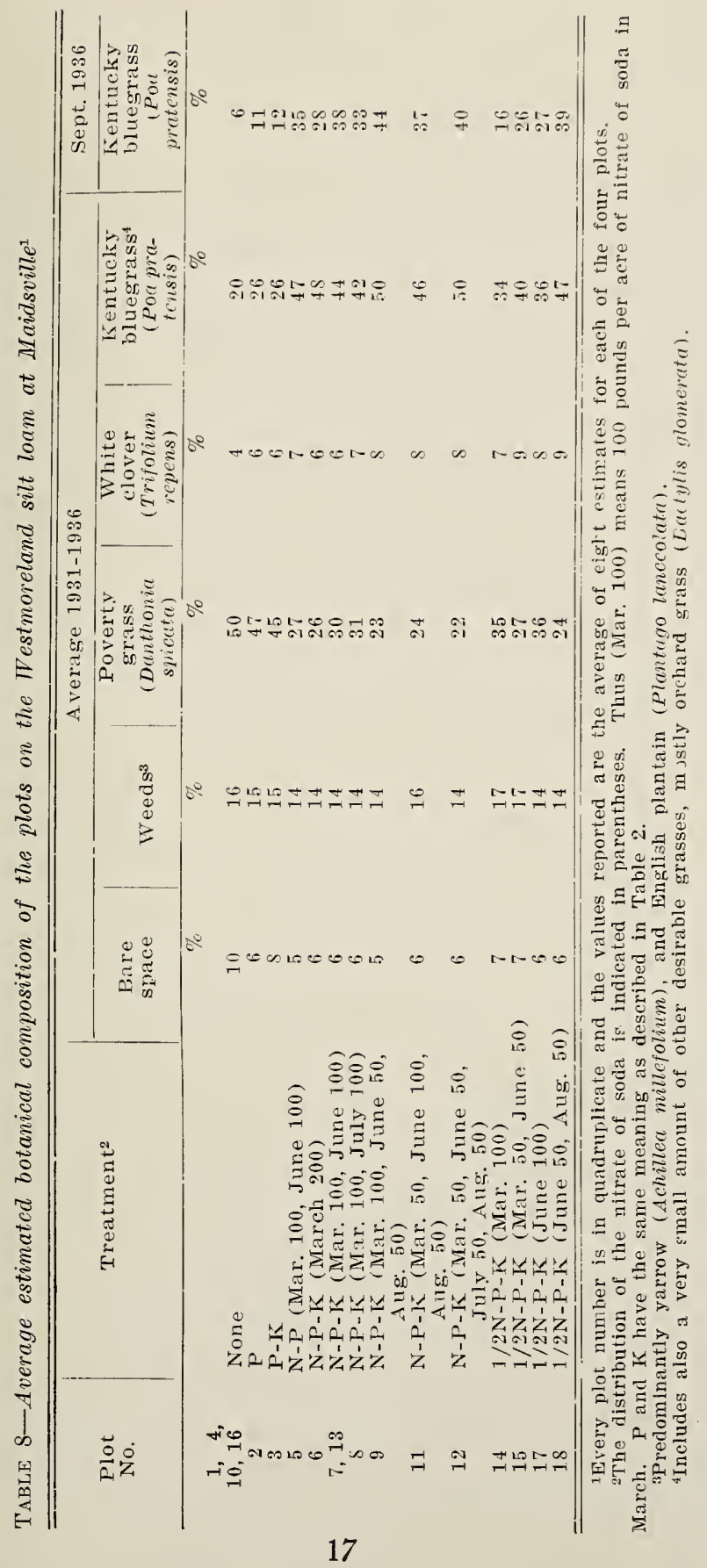


time the experiment was started. The experiment was planned primarily to study the effect of applying nitrogen fertilizer at different times during the year on the incleases in yicld throughout the season. Most of the results of this experiment will be reported in detail in another publication, but some of the results are of interest hrre.

The arerage botanical composition of the various plots for the period 1931-1936 is given in Table 8 . The percentage of total desirable species has areraged $24,32,47$, and 53 , respectively, for the mntreated, P-K, 1/2N-P-K, and N-P-K treatments. Of particular interest, however, are the estimates of Kentucky bluegrass in the fall of 1936 (last column of Table 8 ). The percentage values at that time were directly related to the rate of nitrogen fertilization, being $3 \bar{T}, 2 \bar{T}$, and 12 , respectively, for the $\mathrm{N}, 1 / 2 \mathrm{~N}$, and no $\mathrm{N}$ treatments. These differences emphasize the importance of an adequate supply of available nitrogen in order to maintain a sod of Kentucky bluegrass. When clovers or other legumes are plentiful they supply nitrogen for the growth of bluegrass, but following a series of years unfavorahle for clover, available nitrogen becomes an important limiting factor, especially on clipped plots. It should be recognized, however, that under grazing conditions a large percentage of the nitrogen that is removed in the grass is returmed to the pasture in the droppings. Thus the declease in the percentage of bluegrass in this experiment no doubt was greater than would be expected under grazing.

\section{Wardensville: Fxperiment}

As was stated earlier, the experiment on the Monongahela fine sandy loam at Wardensville differed from the other's in that the area was plowed and reseeded. The initial application of lime and fertilizer was made in the spring of 1931 and disked into the soil. The area was then seeded with a mixture of Kentucky bluegrass, red top, and white clover, using a nurse crop of oats. The oats were harvested early, and later in the season the weeds were cut, but the grass and clover were not clipped until the following spring.

In spite of the high acidity of the soil ( $\mathrm{pH} 4.9$ ) on the plots receiving neither lime nor fertilizer, estimates made in the spring of 1932 show a fairly good stand of red top, white clover, and Kentucky bluegrass. The stand of bluegrass and clover was considerably better, however, on the plots receiving lime and superphosphate. Neither nitrogen nor potash fertilizers had any apparent effect on the total percentage of desirable species, but, as might be expected, nitrogen fertilizers produced a marked reduction in the percentage of white clover. On the limed plots there was no significant difference between the effect of different nitrogen carriers, but on the unlimed plots there were much smaller amounts of clover where the acid-forming carriers of nitrogen were used (Table 9 ). The increase in clover from liming averaged 21 percent for the nonacid-forming carriers of nitrogen (CaInitro and nitrate of soda) as compared with 79 percent for the acid-forming carriers (sulphate of ammonia, urea, and Ammo-phos). 
TABLE 9-Effect of acid-forming and non-acirl-forming nitrogen fertilizers on the estimated percentages of white clover on the Monongahela fine sandy loam at Wardensville, June 1932

\begin{tabular}{|c|c|c|c|c|}
\hline \multirow{2}{*}{$\begin{array}{l}\text { Nitrogen } \\
\text { sources }\end{array}$} & \multirow{2}{*}{ Fertilizer treatment } & \multicolumn{2}{|c|}{$\begin{array}{c}\text { Percentage of white } \\
\text { clover }\end{array}$} & \multirow{2}{*}{$\begin{array}{l}\% \text { increase } \\
\text { in white } \\
\text { cover from } \\
\text { Iiming }\end{array}$} \\
\hline & & $\begin{array}{l}\text { Unlimed } \\
\text { plots }\end{array}$ & $\begin{array}{c}\text { Limed } \\
\text { plots }\end{array}$ & \\
\hline$\cdots \cdots$ & $\mathrm{P}$ and $\mathrm{P}-\mathrm{K}$ & 38 & 13 & 30 \\
\hline \multirow{2}{*}{$\begin{array}{l}\text { Non-acid- } \\
\text { forming }\end{array}$} & N-P-I (nitrate of soda) & 21 & 26 & 24 \\
\hline & N-P-K (calnitro) & 26 & 31 & 19 \\
\hline \multirow{3}{*}{ Acid-forming } & N-P-K (sulfate of ammonia) & 15 & 28 & 87 \\
\hline & $\mathrm{N}-\mathrm{P}-\mathrm{K}$ (urea) & 16 & 29 & 81 \\
\hline & N-P-K (Anmo-phos $)^{1}$ & 10 & 17 & 70 \\
\hline
\end{tabular}

TThe relatively small percentage of clover on these plots undoubtedly resulted from applying all the nitrogen in the spring (Table 5, second footnote).

All the clover was killed by the very dry summer of 1932 , and it was just beginning to come back when it was killed during the hot, dry summer of 1934 . In fact, the plots were so severely injured by moles and dry weather during 1934 that the experiment was temporarily discontinued. The botanical estimates made early in 1934 emphasize the importance of lime and fertilizers in determining the botanical composition of a pasture (Table 10). It will be noted first that, although all plots had received the same seed treatment in 1931, the limed plots were predominantly Kentucky bluegrass in 1934, whereas the unlimed plots were predominantly red top. There was still a good stand of Kentucky bluegrass in 1934 on the plots that received lime but no superphosphate, indicating that the soil contained enough readily available phosphorus to support a stand of Kentucky bluegrass for the first few years after seeding. It should be recognized, however, that the plots were seeded during an unusually favorable year and that equilibrium between the soil and the vegetation had not yet been fully established.

As at Morgantown, the residual effect of the nitrogen fertilizers was very evident on the unlimed plots. Those that received neutral or basic TABLE 10-Effect of soil acidity on the percentage of Kentucky bluegrass and "red top on the Monongahela fine sandy loam at Wardensville, Spring 1934

\begin{tabular}{|c|c|c|c|c|}
\hline \multirow[b]{2}{*}{ Treatment } & \multicolumn{2}{|c|}{ Unlimed } & \multicolumn{2}{|c|}{ Limed } \\
\hline & $\begin{array}{c}\text { Ky. bluegrass } \\
\text { (Poa } \\
\text { pratensis })\end{array}$ & $\begin{array}{l}\text { Red top } \\
\text { (Agrostis } \\
\text { alba) }\end{array}$ & $\begin{array}{c}\mathrm{Ky} \cdot \text { bluegrass } \\
\text { (Poa } \\
\text { pratensis) }\end{array}$ & $\begin{array}{l}\text { Red top } \\
\text { (Agrostis } \\
\text { alba) }\end{array}$ \\
\hline None & 16 & 57 & 60 & 14 \\
\hline $\begin{array}{l}\mathrm{P} \text { and } \mathrm{P}-\mathrm{K} \\
\mathrm{N}-\mathrm{P}-\mathrm{K} \text { (Non-acid }\end{array}$ & 19 & 58 & 62 & 12 \\
\hline carriers of nitrogen) & 37 & 46 & 67 & 11 \\
\hline $\begin{array}{l}\text { N-P-K (acid-forming } \\
\text { carriers of nitrogen) }\end{array}$ & 16 & 65 & 64 & 16 \\
\hline
\end{tabular}


carriers of nitrogen averaged 37 pereent Kientucky bluegrass and 46 percent red top as compared with 16 perecnt Kentucky blueglass and 65 percent red top for the plots receiving acid-forming carriers of nitrogen ('Table 10).

\section{SPENCER TXPERIMENT}

The soil used for the Spencer experiment was very mploductive. and at the time the experiment was started (fall 1934), the estimates showed a total of only 1 percent lientucky bluegrass and white elover. The remaining 99 pereent was composed of native crrasses, weeds, and bare space.

TABLE 11-Estimates of the percentrge of white clover, hop clover, and Fentucliy bluegrass one to $2 \frac{1}{2}$ years after treatment on the Unshur elay at Spencer

\begin{tabular}{|c|c|c|c|c|c|c|}
\hline \multirow{2}{*}{$\begin{array}{l}\text { Treatment of plots } \\
\text { represented }\end{array}$} & \multicolumn{2}{|c|}{1935 (oct. 9) } & \multicolumn{2}{|c|}{1936 (May 19) } & \multicolumn{2}{|c|}{1937 (June 22) } \\
\hline & $\begin{array}{l}\text { White } \\
\text { clover }\end{array}$ & $\begin{array}{l}\text { Kentucky } \\
\text { bluegrass }\end{array}$ & $\begin{array}{l}\text { White } \\
\text { elover }\end{array}$ & $\begin{array}{l}\text { Kentucky } \\
\text { bluegrass }\end{array}$ & $\begin{array}{l}\text { Hop } \\
\text { elover }\end{array}$ & $\begin{array}{l}\text { Kentuclsy } \\
\text { bluegrass }\end{array}$ \\
\hline & $\%$ & $\%$ & $\%$ & $\%$ & $\%$ & $\%$ \\
\hline None & 4 & 2 & 3 & 3 & 19 & 4 \\
\hline I & 11 & 2 & 15 & 3 & 17 & 8 \\
\hline P. P-K & 5 & 4 & 7 & 5 & 21 & 7 \\
\hline $\begin{array}{l}1 / 2 \mathrm{P}-1 / 2 \mathrm{~K}-\mathrm{L} \\
\mathrm{N}-\mathrm{P}-\mathrm{L}, \mathrm{N}-\mathrm{P}-\mathrm{K}-\mathrm{T}\end{array}$ & 15 & 3 & $2 \pi$ & 4 & 34 & 12 \\
\hline $\mathrm{N}-\mathrm{P}-\mathrm{K}-2 \mathrm{~L}$ & 16 & 7 & 27 & 9 & 22 & 20 \\
\hline
\end{tabular}

'See Tables 3 and 4 for more detailed treatments. Since there was no increase in yield or percentage of desirable species from $K$, no greater increase from $P$ than from $1 / 2 \mathrm{P}$ and no apparent difference between 1 he effect of $\mathrm{L}$ and $2 \mathrm{~L}$, a number of the treatments were grouped together in the above table.

As in most of the other experiments, the effect of the treatments was first evidenced by the increase in the percentage of white clover (Table 11). Within one year after treatment the limed plots had nearly three times as much white elover as the untreated plots. When used without lime, phosphorus and potash had little effect on the percentage of white clover, but the combination of lime and phosphorus, with ol without potash or nitrogen, increased the percentage of clover to approximately four times that of the mntreated plots. During 1936 the differences were even greater, the plots receiving phosphorus and lime averaging about 25 percent clover as compared with 3 percent for the untreated plots. Most of the white clover died during the extremely dry summer of 1936 . In the early summer of 1937, hop clover was present in large amounts. As shown in Table 11, even the untreated plots had an average of 19 percent hop clover. This indicates that hop clover can grow on a relatively poor soil. It will be noted, however, that although lime alone or superphosphate alone had little effect on the abundance of hop clover, the combination of lime and phosphorus nearly doubled the amount present. 
Kentucky bluegrass was rather slow in spreading. 'This is not surprising when it is considered that there was less than one percent when the experiment was started. Nitrogen fertilizer's definitely increased the pereentage of bluegrass. The total pereentage of bluegrass in .Jme 1937 was 4 percent for the untreated plots, 12 percent for the plots receiving phosphorus and lime, and 20 percent for those receiving nitrogen in addition to phosphorus and lime. No doubt more bluegrass will spread in the P-L plots as greater amounts of nitrogen become availal,le from the lcgumes present.

\section{Palestine Experinent}

The untreated soil on the Palestine experiment appeared to be the least productive of any of the experimental areas, being very low in available phosphorus (Table 1). Nevertheless, even the untreated plots supported a good stand of common lespedeza, a species that apparently can grow on very unproductive soils. Fertilizers gave marked increases in yield during the first year (as will be shown in 'Table 19), but the change in the pereentage stand of lespedeza was relatively small. As shown in Table 12, large amounts of lespedeza were still present in June 1937, in spite of the fact that the plots had been clipped closely for over two years. Lime had no effect on the percentage of lespedeza, whereas the plots receiving phosphorus alone or phosphorus and lime showed somewhat higher percentages of lespedeza than the untreated plots.

TABLE 12-Estimates of common lespedeza and of white clover on Holston silt loam at Palestine as affected by fertilization and liming

\begin{tabular}{|c|c|c|c|}
\hline \multirow{2}{*}{$\begin{array}{l}\text { Treatment of plots } \\
\text { represented }{ }^{1}\end{array}$} & \multicolumn{2}{|c|}{$\begin{array}{l}\text { Percentage of } \\
\text { common lespedeza }\end{array}$} & \multirow{2}{*}{$\begin{array}{l}\text { Percentage of } \\
\text { white clover } \\
\begin{array}{c}1936 \\
\text { (May 18) }\end{array}\end{array}$} \\
\hline & $\begin{array}{c}1935 \\
\text { (Sept. 6) }\end{array}$ & $\begin{array}{c}1937 \\
\text { (June 22) }\end{array}$ & \\
\hline None & 52 & 46 & 1 \\
\hline & 56 & 41 & 1 \\
\hline $\mathrm{P}, \mathrm{P}-\mathrm{IS}$ & 60 & 56 & 18 \\
\hline P-I. P-K-T, & 56 & 59 & 21 \\
\hline $1 / 2 \mathrm{P}-\mathrm{L}, 1 / 2 \mathrm{P}-\mathrm{I}-\mathrm{L}$ & 59 & 64 & 13 \\
\hline N-P-L, N-P-I-I, N-P-IK-2L & 62 & 58 & 18 \\
\hline
\end{tabular}

${ }^{1}$ See Tables 3 and 4 for detalled treatments. Since there was no increase in yield or percentage of desirable species from $K$, and no consistent difference between $\mathrm{L}$ and $2 \mathrm{~L}$, a number of the treatments were grouped together in the above table.

There appeared to be no Kentucky bluegrass or white elover on the area when the experiment was started, and in the spring of 1937 (21/2 yr. after treatment) the estimates showed only 2 or 3 percent of Kentucky bluegrass on the treated plots. Since a few scattcred plants of bluegrass have become established this species should, of course, spread rapidly on the treated plots. White clover, although more plentiful than Kentucky bluegrass, has made up only a ver'y small percentage stand even on the treated plots except during the early part of the 1936 season. In May 1936 it will be noted (Table 12) that there was approx- 
imately 18 percent white clover on the phosphorus plots. Lime had no significant effect on the percentage of white clover and, as will be seen in T'able 19, no effect on yields.

\section{RELATION BETWEEN THE CHEMICAL PROPIRTIES OF THE SOIL AND THE RESPONSE OF WHITE CLOVER TO LIAE AND SUPERPHOSPIIATE}

It has been shown in Tables 5 to 12 , inclusive, that the treatment of the different pasture areas with lime and fertilizer in most cases has brought about marked decreases in the perecutage of weeds and poor native grasses in the turf and an increase in the percentage of clesirable species, particularly Kentucky bluegrass and white clover. The changes that have taken place, however, have varied with the soil and with the treatment. In general, the use of superphosphate and lime has brought about the most marked improvement in the type of regetation. This does not mean that the pasture soils are well supplied with arailable nitrogen ; many of them are just as deficient in nitrogen as in phosphorus and lime. This was well illustrated by the fact that when legumes were

TABLE 13-Increase in percentage of white clover from use of lime and superphosphate, as related to acidity and readily available phosphorus content of the soils

\begin{tabular}{|c|c|c|c|c|c|}
\hline \multirow{2}{*}{$\begin{array}{c}\text { Location } \\
\text { of } \\
\text { experiment }\end{array}$} & \multirow[b]{2}{*}{ Soil type } & \multirow{2}{*}{$\begin{array}{l}\text { Avajl- } \\
\text { able } \\
\mathbf{P}\end{array}$} & \multirow[b]{2}{*}{$\mathrm{pH}$} & \multicolumn{2}{|c|}{$\begin{array}{l}\text { Increase in \% white } \\
\text { clover }\end{array}$} \\
\hline & & & & $\begin{array}{c}\text { From } \\
\text { super- } \\
\text { phosplate }\end{array}$ & $\begin{array}{l}\text { From } \\
\text { lime }\end{array}$ \\
\hline Morgantown & Dekalb silt loam & 10 & 5.0 & 20 & 22 \\
\hline Aurora & Upshur clay loam & 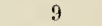 & 5.4 & 29 & 9 \\
\hline Moorefield & Huntington silt 1. & 21 & 5.8 & 8 & 4 \\
\hline Spencer & Upshur clay & 9 & 4.9 & 12 & 20 \\
\hline Palestine & Holston silt loam & $<5$ & 5.3 & 21 & 3 \\
\hline
\end{tabular}

IIncreases from superphosphate obtained by comparing the $\mathrm{L}$ and $\mathrm{P}$ - $\mathrm{L}$ treatments; increases from lime, by comparing the $\mathrm{P}$ and $\mathrm{P}-\mathrm{L}$ and the $\mathrm{P}-\mathrm{K}$ and $\mathrm{P}-\mathrm{K}-\mathrm{L}$ plots.

The percentage of white clover in the P-L plots for the different arcas were as follows: Morgantown, 34; Aurora, 35; Moorefield, 30; Spencer, 27; and Palestine, 22. Estimates at the first three locations are for 1933, and at the last two locations for 1936.

not present, marked increases in the percentage of Kentucky bluegrass were obtained by use of nitrogen. By use of phosphorus and lime, however, white clover and other legumes are eneouraged, and these legumes can supply at least a part of the nitrogen needed by the Kentueky bluegrass and other grasses. It is therefore of eonsiderable practical interest to know to what extent the differences in the responses of white clover to treatments of lime and superphosphate on the different soils can be explained by differences in the $\mathrm{pH}$ and available phosphorus content of the soil.

As previously mentioned, 1933 was a good year for clover on the plots that had been established in 1930, and the early season of 1936 was favorable to clover on the plots established in 1934. The increase in elover resulting from the use of superphosphate and lime for those years is shown in Table 13. Although the use of superphosphate on 
limed plots increased the amount of clover in the vegetation on all soils, it will be noted that the Huntington silt loam, which was considerably higher in available phosphor thas the oiher solls, showed the least response to superphosphate. The other four soils are very low in available phosphorus, and the increase in the percentage of white clover in three of the four eases is over 20 percent. 'T'his increase is particularly striking on the Holston silt loam at Palestine, where the IA plots averaged only one percent white clover and the P-L plots 22 percent. Lime whon used on plots receiving superphosphate increased the percentage of clover in the vegetation from 12 to 34 percent on the Dekalb silt loam and from $i$ to 27 pereent on the Upshur clay. These two soils, as will be noted, are the most acid of the group. The other three soils showed an increase of 3 to 9 percent in the percentage of clover from the use of lime. It would appear from these data that, although white clover still responds to lime on these soils at $\mathrm{pH}$ values of 5.4 to 5.8 , the response is much smaller than on soils of lower pII value. Moreover, it would appear that at least 20 pounds of available phosphorus per two million pounds of the surface three in. of soil are necessary for the optimum amounts of white clover in the herbage. This is in general agreement with results obtained in other investigations in West Virginia ( $\gamma)$.

\section{EFFECT OF LIME AND FERTILIZER ON THE YIELDS OF FORAGE}

\section{Relation of White Clover to Increases in Yields}

The importance of white elover in determining the increases in yield of forage from fertilizer and lime treatments is illustrated in Figure 5. This figmre shows the response to P-K-L and N-P-K-L during two consecutive years at Moorefield and at Wardensville, two areas of similar rainfall and other climatie eonditions. As was explained previously, clover was abundant at Wardensville in 1932 and absent in 1933, whereas at Moorefield elover was present in only small amounts in 1932 but abundant in 1933 . Thus at both Moorefield and Wardensville the response to lime and fertilizer, during a year when clover was absent, can be compared with the response on the same plots during a year when clover was abundant. Moreover, by comparing the response at Wardensville with the response at Moorefield during the same year, it is possible largely to eliminate the effect of seasonal differences. As an average for the two experiments, the P-K-L treatment increased the yield 25 percent when elover was absent and 85 percent when clover was abundant, whereas nitrogen fertilization in addition to P-K-L increased the yield 46 percent when clover was absent but only 4 percent when clover was abundant.

In considering the following yield data, therefore, it should be recognized that the differences in response obtained from year to year are the result not only of differences in weather eonditions and time since the treatments were applied, but also of differences in the abundance of white clover. 


\section{MORGANTOWN FXPLRIMENT}

'The yields of dry herbage from the various lime and fertilizer' 1 reatments on the Dekalb silt loam at Morgantown are summarized in Table 14. Since the soil selected for this experiment is strongly acicl and very low in available phosphorus (Table 1 ), it is not surprising that neither lime alone nor superphosphate alone gave satisfactory increases in yields. Potash gave marked increases in yield on the limed plots but had no apparent effect on the yield of the unlimed plots. The average increases from L, P, P-L, and P-K-I were 19, 36, 64, and 99 perent, respectively. The very heary applications of superphosphate thus far have given only slightly higher yields than the moderate applications,

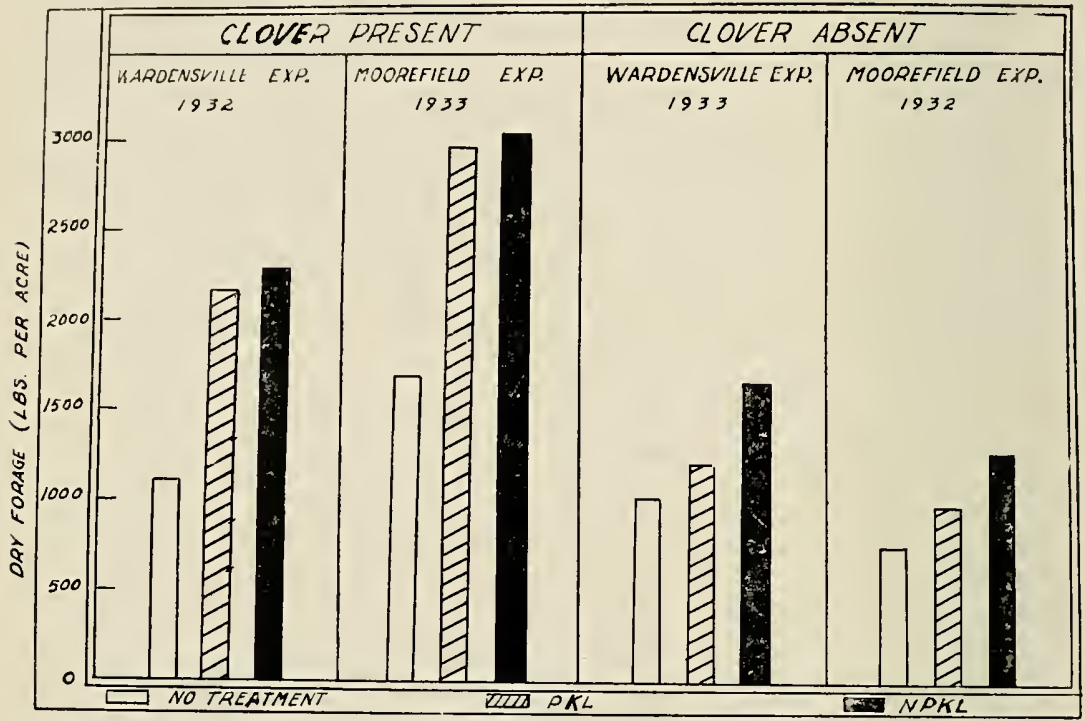

\section{FIG.5. THE EFFECT OF THE PRESENCE OF WHITE CLOVER ON THE RESPONSE OBTAINED WITH LIME AND DIFFERENT FERTILIZERS.}

but the effect will undoubtedly last longer. Nitrogen fertilizers, especially when used in large amounts, produced marked increases in yields. A comparison of the increases in yields from nitrate of soda, sulphate of ammonia, Calnitro, and urea shows that on the limed plots no single nitrogen carrier has given consistently higher yields than the other's, although during single year's there have been differences. On the unlimed plots, sulphate of ammonia gave considerably lower yiejds after the first few rear's. Undoubtedly this difference was due to the residual acidie effect of the sulphate of ammonia.

In order to determine the response to any one fertilizer element, it is necessary first to supply all other limiting elements. 'The response to nitrogen fertilizers, for example, must be determined by comparing the rields of the P-K-L plots with the yields of the N-P-K-L plots, be- 


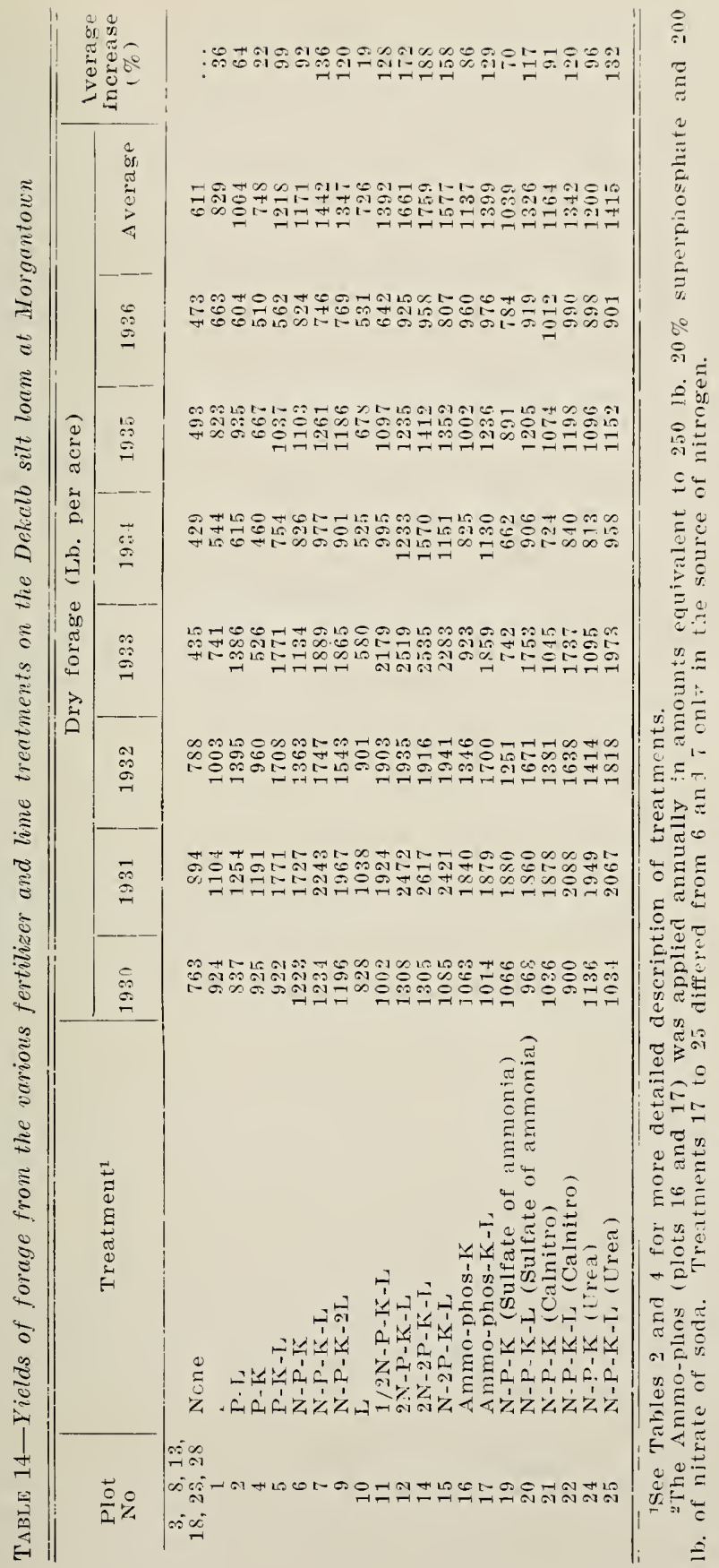


cause $P$, K. and $L$ are all limiting factors on this soil. 'The inerease in rield determined in this manner for the rarious fertilizer elements is shown in Figure 6. The response to phosphorus. however, is underestimated because it could be determined only on plots that had not received potash. During the first year of the experiment the scason was very unfavolable because of the dry summer and fall, and consequently lime, superphosphate, and potash, all of which penetrate very slowly when applied as a topdressing, gave relatively little increases in rield; in fact, lime produced a slight decrease in vield during the first year on most of the plots.

During 1931 to 1933 , with favolable seasons and rapid increases in the percentages of Irentucky bluegrass and white clover on the plots receiving both lime and superphosphate, there were large increases in yield from lime, superphosphate, and potash. It is interesting to note, however, that lime in addition to $\mathrm{X}-\mathrm{J}^{\prime}-\mathrm{K}$ gave smaller increases in yield than lime in addition to P-K. Apparently this difference can be attributed at least partly to differences in the botanical composition of the plots. There was but little clover on any of the unlimed plots, but on the P-K-L plots clover accounted for a considerable portion of the total yield. Nitrogen fertilizers in addition to P-K-L, however, materially decreased the proportion of white clover in the clipped forage. Thus there was more difference between the clover content of the P-K and the P-K-L plots than between that of the N-P-K and the N-P-K-L plots. Since white clover responds more to lime than do the grasses, it is not surprising that the greatest response to lime was obtained where conditions were most favorable for the presence of clover.

The relatively small increases in yield from superphosphate, potash, and lime during 1934 and 1936 , compared with the increases during 1931-1933, undoubtedly are due at least partly to the less favorable growing seasons and to the small percentages of clover on the area. The latter can be accounted for partly by the unfavorable seasons.

When comparing the response to different amounts of nitrogen during different years, as shown in Figure 6 , it should be remembered that with the $1 / 2 \mathrm{~N}$ treatment all the nitrogen was applied in the spring, whereas with the $2 \mathrm{~N}$ treatment half of the nitrogen was applied in the spring and half in midsummer. Moreover, the increase in yield from nitrogen fertilization depends partly on the frequency of cutting. If cutting is done shortly after applying the nitrogen, or if growing conditions are unfavorable because of low tempcrature or dry weather, there will be a relatively greater increase in the nitrogen content of the herbage than in the rield of herbage. If, on the other hand. the time of cutting is delayed and conditions are favorable for growth, the nitrogen will be utilized more for increased growth than for an increase in the nitrogen content of the herbage. This may partly account for the large increase in yield from the $2 \mathrm{~N}$ treatment in 1931, since very good growth followed both the spring and the summer application of nitrogen. Moreover, the amounts of white clover on the area in 1931 were relatively 
low. In 1932 there was so much white clover in the early spring that the response to nitrogen was relatively small, whereas in the latter part of the season it was too dry for efficient utilization of the summer ap)plication of nitrogen. The 1933 season was unnsually good for pasture

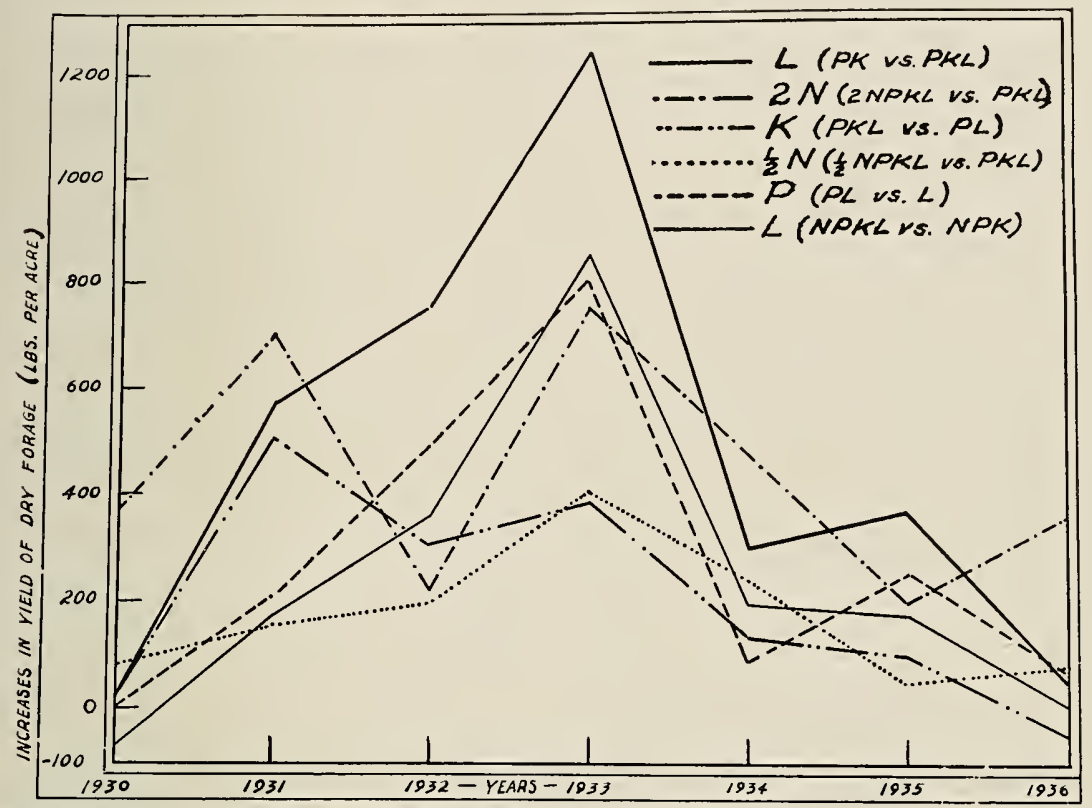

YG.6 INCREASES IN YIELDS OF DRY FORAGE FROI VARIOUS FERTILIZER ELEMENTS ON TI,E DEKALB SILT LOAM AT MORGANTOWN [ ALL PLOTS RECEIVING THE OIFFERENT SOURCES OF NITROGEN WERE CONSIDERED IN DETERNINING THE, RESPONSE TO L (NPKL VS NPK)]

growth and there was a large increase in yield from heavy nitrogen fertilization. Moreover, more than half of the increase occurred following the summer application of nitrogen on June 30 in spite of a rather high percentage of white elover on the area during that period. During 1934 the season was very dry until the latter part of July (Figure 1) and there was little response to the spring application of nitrogen. Over one-half of the increase from the $2 \mathrm{~N}$ treatment occurred during a period of rainy weather in late July and August. The poor response to nitrogen in 1935 , when there was relatively little clover. is attributed partly to the eold weather in the early spring. together with the dry weather during the latter part of the summer. The increase in yield from nitrogen fertilization was also small during the very dry season of 1936.

\section{Aurora Expertment}

The yields of forage clipped from the various lime and fertilizer treatments on the Upshur soil at Aurora are summarized in Table 15. No significant increase was noted in yield from the use of lime on this 


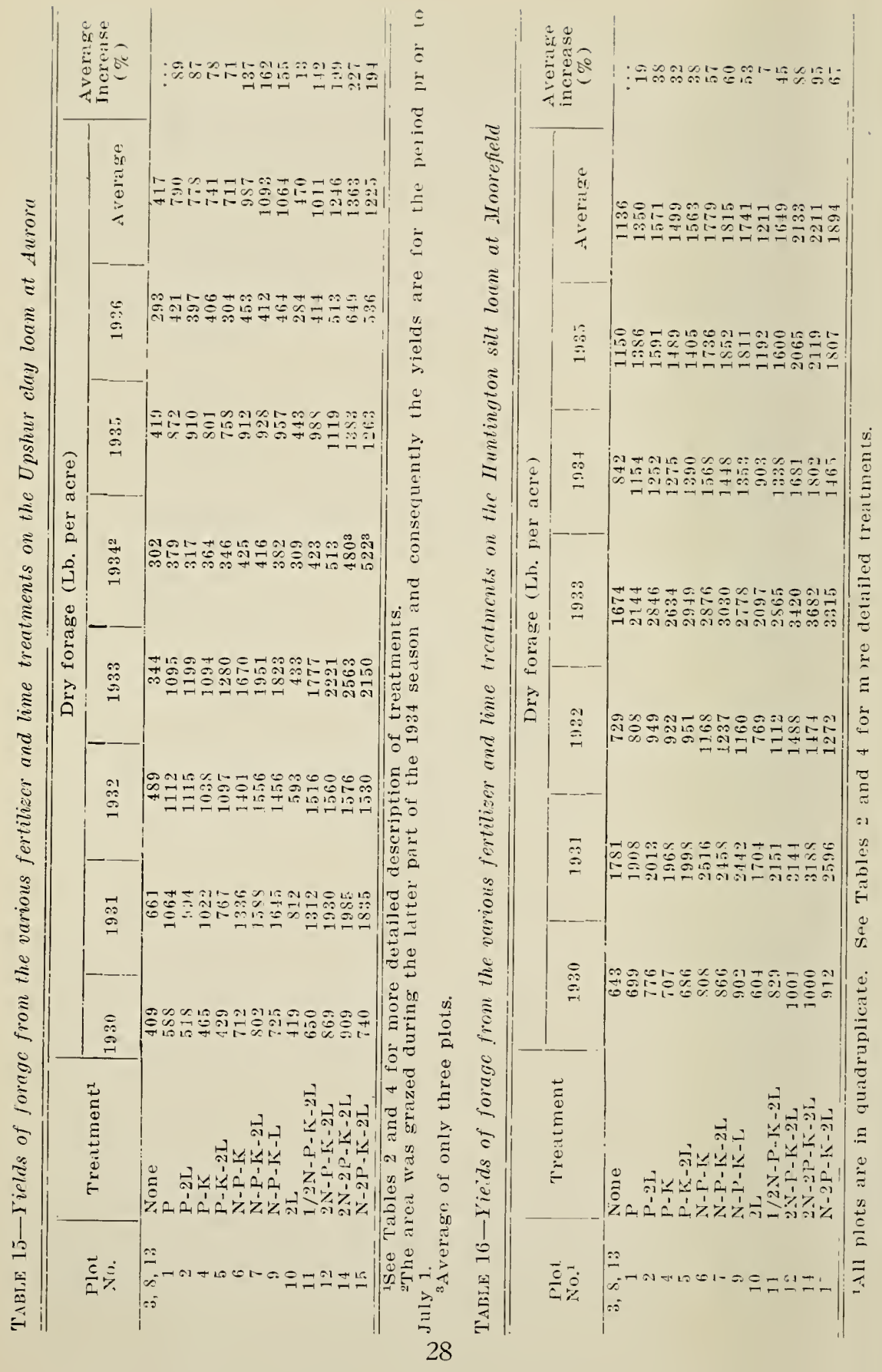


soil, although the $\mathrm{pH}$ of the unlimed soil was about 5.4. Muriate of potash also gave no increase in vield. Superphosphate alone increased the yield 89 percent, and the $2 \mathrm{~N}-2 \mathrm{P}-\mathrm{K}-2 \mathrm{I}$ treatment produced an average increase of 227 percent. Since neither lime nor potash gave any inerease in yield, this 227 pereent inerease must have been due to the superphosphate and nitrogen fertilizers. The average increase in yield from the $2 \mathrm{P}$ treatment, compared with the $\mathrm{P}$ treatment, was relatively small. A comparison of the yields during different years, however, shows that for the first three years the P treatment was as effective as the $2 \mathrm{P}$ treatment, but thereafter there were marked increases in yield from the additional amount of superphosphate.

The increases in yield from the various fertilizer elcments, calculated in the same way as for the Morgantown experiment, are given in Figure 7. The response to superphosphate increased rapidly during the first four years, when there were rapid increases in the percentage of Kentucky bluegrass and white elover. There was but little inerease in yield from superphosphate during the very dry years of 1934 and 1936, the increase in 1934 being especially low because, as shown in Table 15,

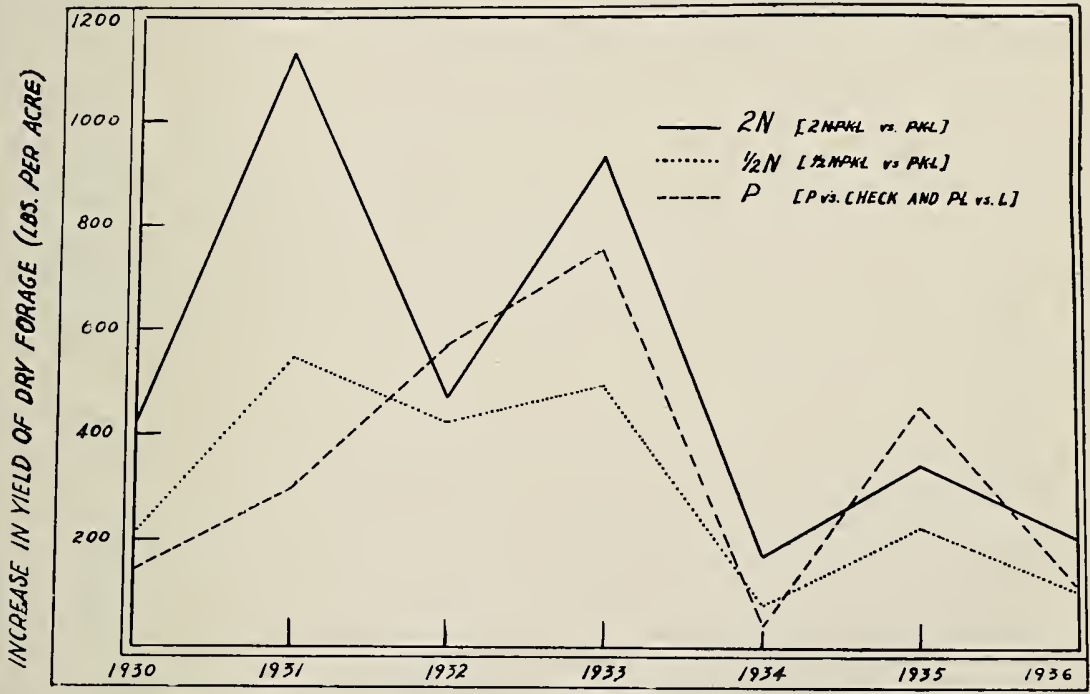

\section{FIG7 INCREASE IN YIELD OF DRY FORAGE FROM SUPERPHOSPHATE AND NITROGEN ON THE UPSIUR CLAY LOAM AT AURORA (LIME AND POTASH WERE OMITTED, BECAUSE THEY GAVE NO INCREASE ON THIS SOIL)}

no yields were obtained after the first of July. There was considerably more rainfall in 1935 than in 1934 or 1936 (Fig. 1), and the response to superphosphate was considerably greater.

The increases in yield from nitrogen fertilization were dependent largely upon the season. In 1930 there was a good response during the 
early part of the season. The months of July, August, and September were very dry, howere", and since the total yields during this period were small, there was little response to nitrogen. In 1931, with good growing weather and but littlo clorer mutil late in the season, there was a very marked response to nitrogen fertilization. The marked response in 1932 to the $1 / 2 \mathrm{~N}$ treatment is rather surprising in view of the excellent stand of white clover. The relatively smaller increase in yield from the $2 \mathrm{~N}$ treatment in 1932 is attributed partly to the extremely dry weather following the summer application of nitrogen and partly to the high percentage of white elorer on the area. (As was pointed out earlier, the $2 \mathrm{~N}$ treatment deereased the pereentage of elover but the $1 / 2 \mathrm{~N}$ treatment did not.) During 1933 there was also a marked response to nitrogen fertilizer, but the inerease oecurred almost entirely before the first of June, when clover was not a very important factor. After June 1 the pereentage of clover was so high on the P-K-L plots that there was little further increase in yield from nitrogen fertilizer. The seasons of 1934 and 1936 were so dry that there was little growth on any of the plots and consequently the inereases in yield from nitrogen fertilization were small. Moreover, as explained previously, no yields were obtained in 1934 after the first of July. The reason for the relatively small response to nitrogen fertilizers in 1935 is not known.

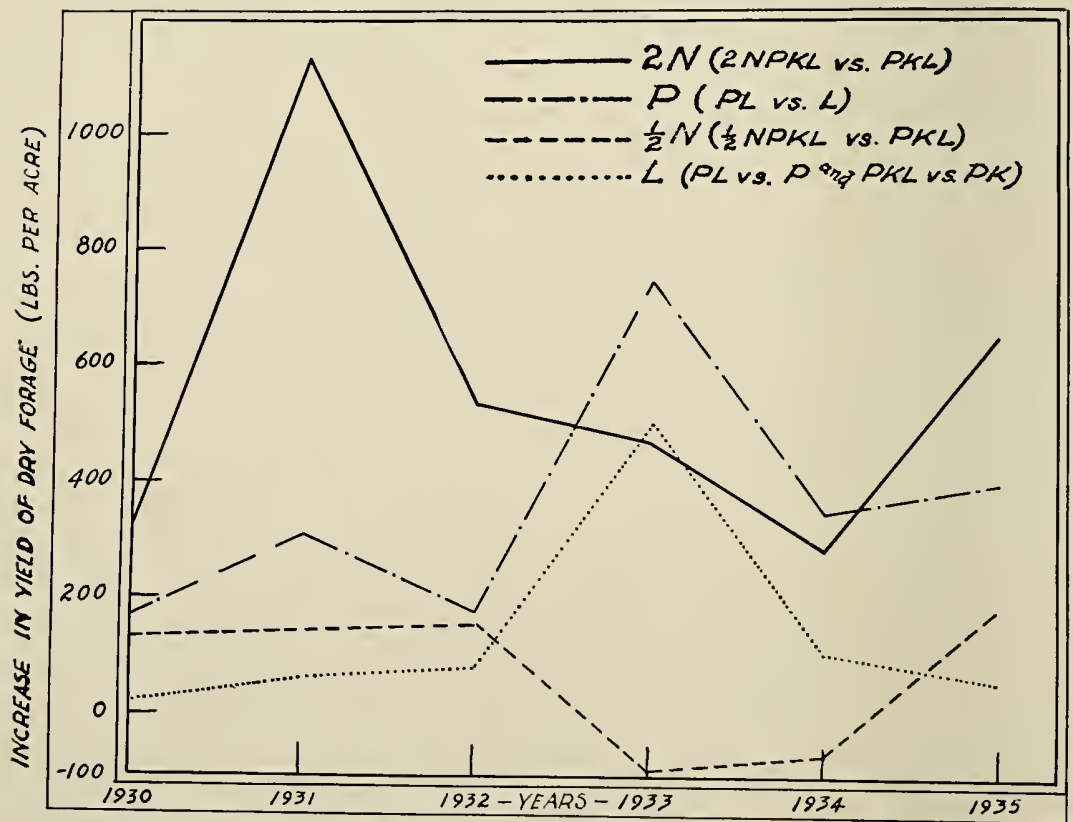

FIG. 8 INCREASES IN YIELOS OF DRY FORAGE FROM VARIOUS FERTILIZER ELEMENTS ON THE HUNIINGTON SILT LOAM AT MOOREFIELD. 


\section{MoOREFIELT Fixi'eriment}

Table 16 gives a summary of the vields of forage obtained on the Huntington soil at Mooreficld. Is was stated earlicr, this soil is much more fertile than the ones at Mergantown and at Amora (see Table 1 ). This is also apparent from the relatively high yields of the untreated plots. The percentage increases in yield from fertilization and liming, therefore, were much lower than at Morgantown or at Aurora, although the actual increases in yield were about the same. The average increases in yield from the $2 \mathrm{~L}, \mathrm{P}, \mathrm{P}-2 \mathrm{~L}$, and $2 \mathrm{~N}-2 \mathrm{P}-\mathrm{K}-2 \mathrm{I}$, treatments were 7,19 , 38,38 , and 95 percent, respectively.

The increases in yield from the various fertilizer elements are shown in Figure 8. During the first three years, when there was but little clover on the area, the inereases in yicld from superphosphate were small. During 1933, however, with a high percentage of white clover and unusually good growing weather, there was a large increase in yield from superphosphate. In 1934, with considerable white clover in the spring but with a short growing season due to dry weather, the actual increase in yield was much smaller than in 1933 , although the percentage increase was about the same. There was also a substantial increase in yield in 1935, when there was relatively little clover, but the percentage increase was somewhat less than in 1933 and 1934.

Lime inereased the yicld when white clover was abundant but had no apparent effect on the growth of Kentucky bluegrass other than that resulting from increased growth of clover.

It is interesting to note that when clover was absent the increases in yield from the $1 / 2 \mathrm{~N}$ treatment were surprisingly uniform, averaging about $150 \mathrm{lb}$. per acre, whereas during the two years when clover was present the same treatment decreased the yield, presumably because of decreasing the percentage of clover.

The $2 \mathrm{~N}$ trcatment gave a large increase in yield in 1931 , when rainfall was well above normal and when clover wis absent. The smaller increase in 1933 was due largely to the high percentages of clover on the plots receiving no nitrogen fertilizer. The poor response to the $2 \mathrm{~N}$ treatment in 1934 is attributed partly to the presence of clover during the early part of the season and partly to the prolonged dry period during the summer. In 1930, 1932, and 1935 the small increases were due partly to the relatively poor growing weather following the summer applications of nitrogen; in 1932 no cuttings were made after that time.

As was noted earlier, even the 100 -lb. application of nitrate of soda decreased the percentage of clover on the Moorefield experiment. This decrease in the percentage of clover explains the decrease in yield during the years when clover was abundant. With heavy nitrogen fertilizer, however, the increased growth of Kentucky bluegrass more than overbalanced the effect of the decrease in clover. Thus it appears that on a good sod of Kentucky bluegrass, even light applications of nitrogen may stimulate the growth of Kentucky bluegrass and thereby crowd out 


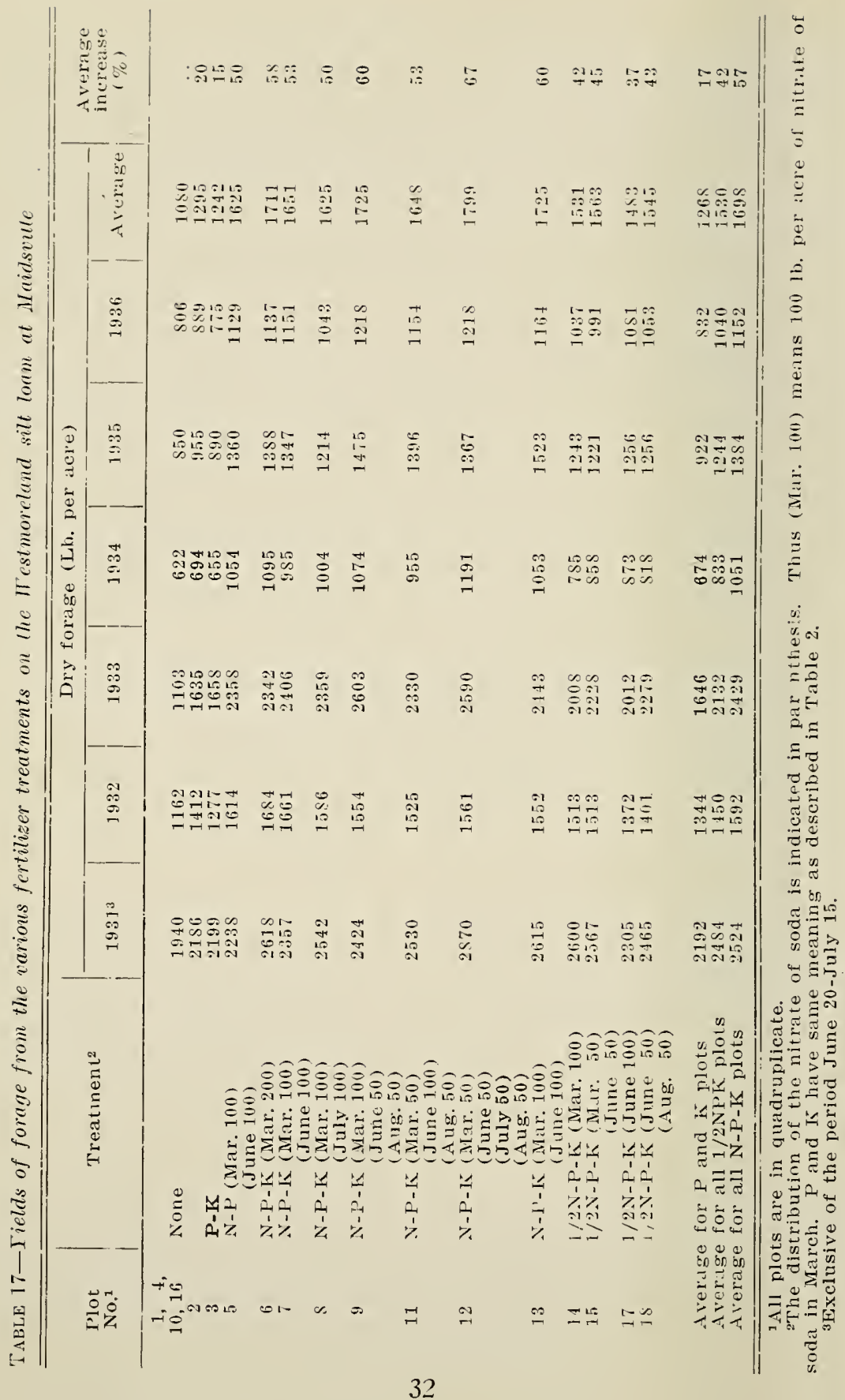


part of the clover. It should be recognized, however, that the height and frequency of clipping are also important factols determining the relative pereentages of Kentucky hluegrass and white (dover. Ender goorl grazing practices where the grass is not allowed to get very high, the nitrogen would probably have had a much lesser effect in reducing the percentage clover than under the conditions of these exporiments.

This area reccived a deposit of from 2 to $5 \mathrm{in}$. of silt during the flood in March 1936 ; eonsequently the studies were discontinued.

\section{Maidsville Experiment}

The yields of forage from the various fertilizel treatments on the Westmoreland silt loam at Maidsville are given in Table 17. Potash gave no increase in yield on this soil, and the increase from superphosphate alone was relatively small, averaging only 20 percent. Unfortunately, the response to superphosphate was not determined on plots receiving nitrogen fertilizer. The increase would no doubt have been considerably greater had available nitrogen not been an important limiting factor. As shown in Figure 9, the greatest increase in yield from phosphorus was obtained during 1933, which season was very favorable for pasture growth. The season of 1931 was also farorable, but the superphosphate had not had time to penetrate into the soil and become available to the plants. The small inereases in yield from superphosphate in 1934 to 1936 appear to be due partly to the unfavorable

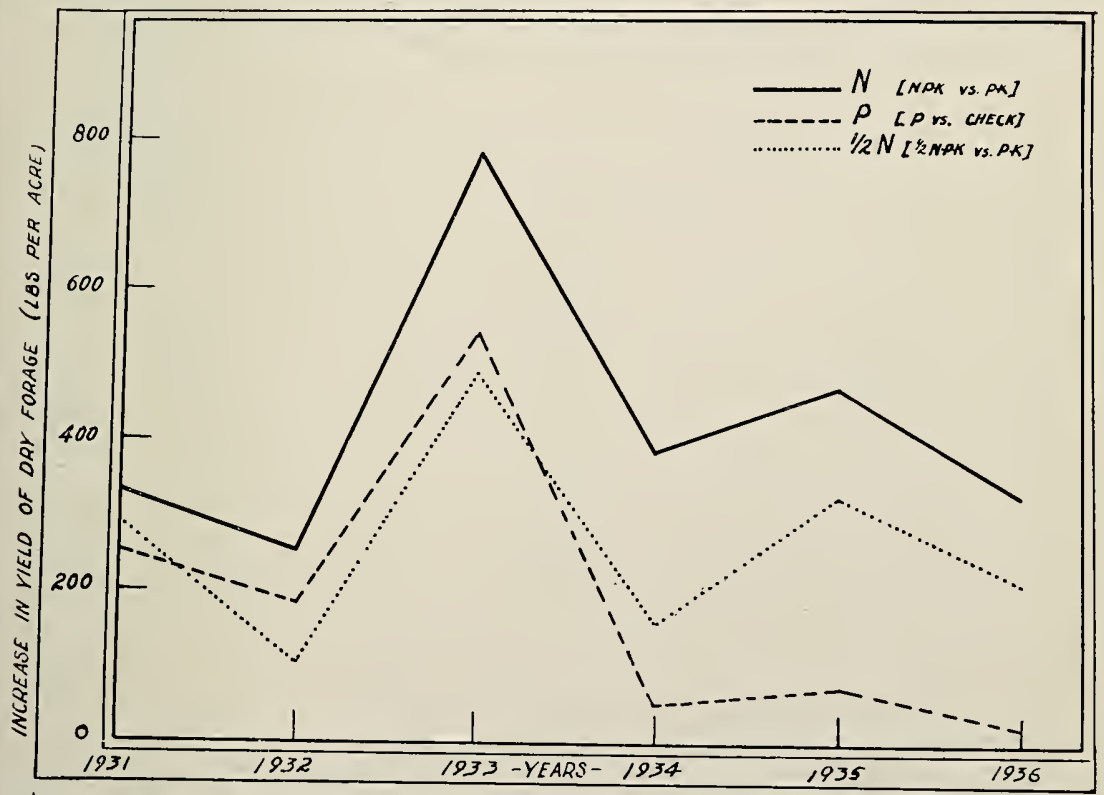

FIG. 9 INCREASE IN VIELDS OF DRY FORAGE FROM VARIOUS FERTILIZER TREATMENTS ON THE WESTMORELAND SILT LOAM AT MAIOSVILLE. 
seasons and partly to a marked deficiency in available nitrogen on the plots where the response to superphosphate was determined. Practically no white clover was present on the plots after 1933, the early summer drought of 1934 having killed the clover;

There were marked inereases in yield from nitrogen fertilization. The average inerease in yield per unit of nitrogen fertilizer was about the same regardless of the 1 ime of application.

\section{Wardeastille Experiment}

The small plot experiment at Wrardensville was diseontinued temporarily after the spring of 193 ! because of injury from moles and dry weather and the consequent appearanee of numerous weeds. The yields obtained during 1932 and 1933 are summarized in 'Table 18. As was stated earlier, white clover was abundant in 1932 and absent in 1933. This difference in botanical composition had a marked effeet on the response to lime and fertilizer treatments. In 1932 there were marked inereases in yield from lime and superphosphate ( 83 pereent) but no inerease from nitrogen fertilization exeept where large amounts had been applied. On the other hand, in 1933 the increase from phosphorus and lime was only 16 pereent, whereas with the addition of nitrogen (N) it was raised to 55 pereent, and the increase in yield from the $2 \mathrm{~N}-\mathrm{P}-\mathrm{K}-\mathrm{I}$, treatment was 103 pereent. Muriate of potash gave an additional in-

TABLE 18-Yields of forage from the various fertilizer and lime treatments on the Monongahela fine sandy loam at Tiardensville

\begin{tabular}{|c|c|c|c|c|c|}
\hline \multirow{2}{*}{$\begin{array}{l}\text { Plot } \\
\text { No. }\end{array}$} & \multirow{2}{*}{ Treatment } & \multicolumn{2}{|c|}{$\begin{array}{l}\text { Dry forage } \\
\text { (Lb. per acre) }\end{array}$} & \multicolumn{2}{|c|}{$\begin{array}{c}\text { Percentage } \\
\text { increase in yield }\end{array}$} \\
\hline & & 1932 & 1933 & 1932 & 1933 \\
\hline $3,8,13$, & & & & & \\
\hline$i^{183}$ & $\mathrm{P}_{\mathrm{P}}^{\text {None }}$ & $\begin{array}{l}1105 \\
1607\end{array}$ & $\begin{array}{r}993 \\
1187\end{array}$ & $\dddot{45}$ & $\ddot{20}$ \\
\hline 2 & P-2I & 2021 & 1148 & 83 & 16 \\
\hline 4 & $\mathrm{P}-\mathrm{K}$ & 1516 & 1078 & 37 & 9 \\
\hline 5 & P-K-2L & 21.61 & 1189 & 96 & 20) \\
\hline 6 & $\mathrm{~N}-\mathrm{P}-\mathrm{K}$ & 1860 & $164 \mathrm{~S}$ & $6 \mathrm{~S}$ & 66 \\
\hline 7 & $\mathrm{~N}-\mathrm{P}-\mathrm{K}-2 \mathrm{~L}$ & 2280 & 1639 & 106 & 65 \\
\hline 9 & N-P-K-L & 2137 & 3718 & 93 & 73 \\
\hline 10 & $2 \mathrm{~L}$ & 1377 & 1054 & 25 & 6 \\
\hline 11 & $1 / 2 \mathrm{~N}-\mathrm{P}-\mathrm{K}-2 \mathrm{~L}$ & 2416 & 1392 & 119 & 40 \\
\hline 12 & $2 \mathrm{~N}-\mathrm{P}-\mathrm{K}-2 \mathrm{~L}$ & $251 \S$ & 2018 & $12 \mathrm{~S}$ & 103 \\
\hline 14 & $2 N-2 P-K-2 L$ & 2776 & 2303 & 151 & 132 \\
\hline 15 & $\mathrm{~N}-2 \mathrm{P}-\mathrm{K}-2 \mathrm{~L}$ & 2619 & $172 \mathrm{~s}$ & 137 & 74 \\
\hline 16 & Ammo-phos-K & 1771 & 1640 & 60 & 65 \\
\hline 17 & Ammo-phos-K-2L & 2195 & 1636 & 99 & 65 \\
\hline 19 & $\begin{array}{l}\text { N-P-TK } \\
\text { (Sulfate of ammonia) }\end{array}$ & 1666 & 1564 & 51 & $j S$ \\
\hline 20 & $\begin{array}{l}\mathrm{N}-\mathrm{P}-\mathrm{K}-2 \mathrm{~L} \\
\text { (Sulfate of ammonia) }\end{array}$ & 2246 & 1735 & 103 & 75 \\
\hline 21 & $\mathrm{~N}-\mathrm{P}-\mathrm{K}$ (Calnitro) & 1841 & 1606 & 67 & 62 \\
\hline 22 & N-P-K-2L (Calnitro) & 2124 & 1601 & 92 & 61 \\
\hline 24 & N-P-K (Urea) & 1524 & 1467 & 38 & 48 \\
\hline 25 & N-P-I-2L (Urea) & $208 s$ & 1514 & $\$ 9$ & 52 \\
\hline 26 & $\mathrm{~N}-\mathrm{P}-2 \mathrm{~L}$ & 2042 & 15.38 & 85 & 55 \\
\hline
\end{tabular}

${ }^{1}$ All plots are in quadruplicnte. See Tables 2 and 4 for more detailed description; also Table 5 , second footnote. 
crease over lime, phosphorus, and nitrogen of 21 pereent in 19:32, when elover was abundant, and of 10 pereent in 1933, when elover was absent. In addition to the small-plot experiment there were also established in this area large plots of $4 \frac{1 / 2}{2}$ to 6 acres, where the response to fertilization and liming was measured by grazing. Some of the results of this experiment have been reported in another publication (10), but it should be emphasized here that the percentage increases in yields from various treatments were very similar for the clipped and for the grazed plots.

\section{Palestine Experiment}

The yield data from the Palestine experiment are given in Table 19. The surprising feature of these results is the very high yields obtained in 1935 from the untreated plots which, as shown in Table 1, are very low in fertility. Sinee these high yields were due largely to the growth of lespedeza, they show the importanee of this species for unproduetive soils. Superphosphate alone, however, gave an increase in yield of 57 pereent during the first season after treatment, showing that lespedeza responds well to fertilization. There was a marked additional inerease in yield from nitrogen fertilizer and a small inerease from the use of lime, but little or no response from potash. In 1936 the season was so dry that the yields were very low on all plots, and the increases in yield eonsiderably less than in $\mathbf{1 9 3 5}$.

Yield data are not reported for the Spencer experiment, since the yields from replieated plots were quite variable and sinee only two years' data are available.

TABLE 19-Fields of forage from the various fertilizer and lime treatments on the Holston silt loam at Palestine

\begin{tabular}{|c|c|c|c|c|c|}
\hline \multirow{2}{*}{$\begin{array}{l}\text { Plot } \\
\text { No.1 }\end{array}$} & \multirow{2}{*}{ Treatment } & \multicolumn{2}{|c|}{$\begin{array}{c}\text { Dry forage } \\
\text { (lb. per acre) }\end{array}$} & \multicolumn{2}{|c|}{$\begin{array}{c}\text { Percentage } \\
\text { increases in yield }\end{array}$} \\
\hline & & 1935 & 1936 & 1935 & 1936 \\
\hline 3,8 & None & 1698 & 531 & & \\
\hline 1 & $\mathrm{p}$ & 2668 & 669 & $\ddot{5} \dot{7}$ & $\dot{2} \dot{6}$ \\
\hline 2 & P-L & 2732 & 601 & 61 & 13 \\
\hline 4 & P-K & 2580 & 661 & 52 & 24 \\
\hline 5 & $\mathrm{P}-\mathrm{K}-\mathrm{I}$ & 2726 & 693 & 61 & 31 \\
\hline 6 & $\mathrm{~N}-\mathrm{P}-\mathrm{K}$ & 3014 & 749 & $7 \mathrm{~s}$ & 41 \\
\hline 7 & $\mathrm{~N}-\mathrm{P}-\mathrm{K}-\mathrm{L}$ & 3159 & $\$ 16$ & 86 & 54 \\
\hline 9 & $\mathrm{~N}-\mathrm{P}-\mathrm{K}-2 \mathrm{~L}$ & 3577 & 828 & 111 & 56 \\
\hline 10 & $\mathrm{~L}$ & 1868 & 553 & 10 & 4 \\
\hline 12 & N-P-L & 3241 & 830 & 91 & 56 \\
\hline 13 & $1 / 2 \mathrm{P}-\mathrm{L}$ & 2554 & 569 & 50 & 7 \\
\hline 14 & $1 / 2 \mathrm{P}-1 / 2 \mathrm{~K}-\mathrm{L}$ & 2735 & 670 & 61 & 26 \\
\hline
\end{tabular}
ments.

${ }^{1}$ All plots are in quadruplicate. See Tables 3 and 4 for more detailed treat-

\section{FACTORS TO BE CONSIDERED IN INTERPRETING THE YIELD AND O'THER DATA.}

In order to get a proper understanding of the response of permanent pastures to fertilization and liming, particularly as measured by the weight of elippings, it is necessary to consider three important points : (1) The residual effect of lime and fertilizers over a number of year's 
is considerable, (2) yick data alone do not shoow the difference in the kind of herbage and in the nutritive value of the herbage found on treated and untreated plots, and (3) plots clipped with a lawmower may show lower yields and lower amounts of desirable species than grazed plots, since no manure is returned.

\section{Residtal Erfect of Lime and Fertilizer}

In order properly to evaluate the results obtained from experiments with fertilizer and lime on permanent pastures, it is neressary to know not only the increase obtained during the first few years but also the residual effect of the fertilizer and line. The importance of this residual effect is shown by an experiment started on the Dairy IInsbandry Farm at Morgantown in 1923. At that time 880.05 -acre plots were established on an old upland pasture and topdressed with various combinations of lime, fertilizer, and mannre, with and without reseeding. From 1924-1928 inclusive, one-half of each plot was protected from grazing and the yield of hay and aftermath determined. The other half of each plot was grazed but no yields determined. Periodic botanical estimates were made on both the grazed and the ungrazed areas. The results of this study were published in 1930 (5). The plots, however, are still in permanent pasture. On a part of this area no lime has becn applied since 1923 and no fertilizer or manure since 1927. Studies of the residual effect of the lime and fertilizer on the botanical composition, the yield of clipped forage, and the acidity and available phosphate content of the soil are bcing conducted. Only a summary of some of the data obtained will be reported here.

The residual effect of lime and phosphorus on the botanical composition of the vegetation in the fall of 1936 is shown in Table 20. The untreated plots averaged 7 percent desirable species as compared with 40 percent for the plots that received lime in 1923. The residual effect of the phosphorus is much smaller that that of ime but is probably as great as could be expected because the phosphoms treatment consisted of only 600 pounds of $16 \%$ superphosphate applied half in 1023 and half in 1927. On the basis of the botanical estimates the carring capacity was calculated, using the standard proposed as a result of other

TABLE 20-Residual effect of time and superphosphate applied as a topdressing to a. permanent pasture, nine to thirtcen years previousl!"

\begin{tabular}{|c|c|c|c|}
\hline $\begin{array}{l}\text { Fertilizer } \\
\text { treatment }{ }^{1}\end{array}$ & $\begin{array}{l}\text { No, of plots } \\
\text { averaged }\end{array}$ & $\begin{array}{c}\text { Total desirable } \\
\text { species in } 1: 36^{2} \\
(\%)\end{array}$ & $\begin{array}{c}\text { Calculated carry - } \\
\text { ing capacity } \\
\text { (Acres per animal } \\
\text { unit) }\end{array}$ \\
\hline None & 5 & 7 & 5.5 \\
\hline & 5 & 40 & 3.0 \\
\hline $\mathrm{P}$ & 6 & 14 & 5.0 \\
\hline P-I & 6 & 50 & $2 . \overline{5}$ \\
\hline
\end{tabular}

${ }^{1} \mathrm{P}=600 \mathrm{lb}$. per acre of $16 \%$ superphosphate applied half in 1923 and half in $192 \pi$.

$\mathrm{L}=30001 \mathrm{~b}$. per acre of hydrated limo in 1923 clovers.

Kentucky bluegrass with small amounts of red top and white, rod, and hop

${ }^{3}$ Based on standard by which the carring capacity can be estimated directly from the percentage of total desirable species $(\gamma)$. 
investigations ( $y$ ). By means of this standard the carrying capacity can be estimated directly from the perentage of total desirable species. The results (Table 20 ) indicate that the carrying capacity of the plots that received phosphorus and lime is still about twice as high as that of the untreated plots.

The reason for the large residual effect from lime is evident from the soil acidity data presented in Figure 10. Where no lime had been applied since 1923 , the surface $0-11 / 2$ in. of soil had a pH of 5.2:3, and the lower layers approximately pH 5.0. In contrast, the pH value of the limed plots was 6.98 in the surface $0-1 \frac{1}{1} 2$ in., and the $\mathrm{pH}$ of the lower layers 5.57 to 6.31 . Thus it is evident that although some of the lime has penetrated into the soil suffieiently to lower the acidity of the 5-7 in. layer, most of it has remained to mentralize the surface layers where the roots of the pasture plants are most abundant.

In the present experiments the residual effect of lime and superphosphate as measured by soil analysis was determined in 1934. Some of the results obtained at that time are summarized bricfly in Table 21. The 2L treatment increased the pII of the surface 11/2-in. layer of soil from 5.71 to 6.79 at Mooreficld and from 5.32 to 6.42 at Aurora. The $L_{s}$

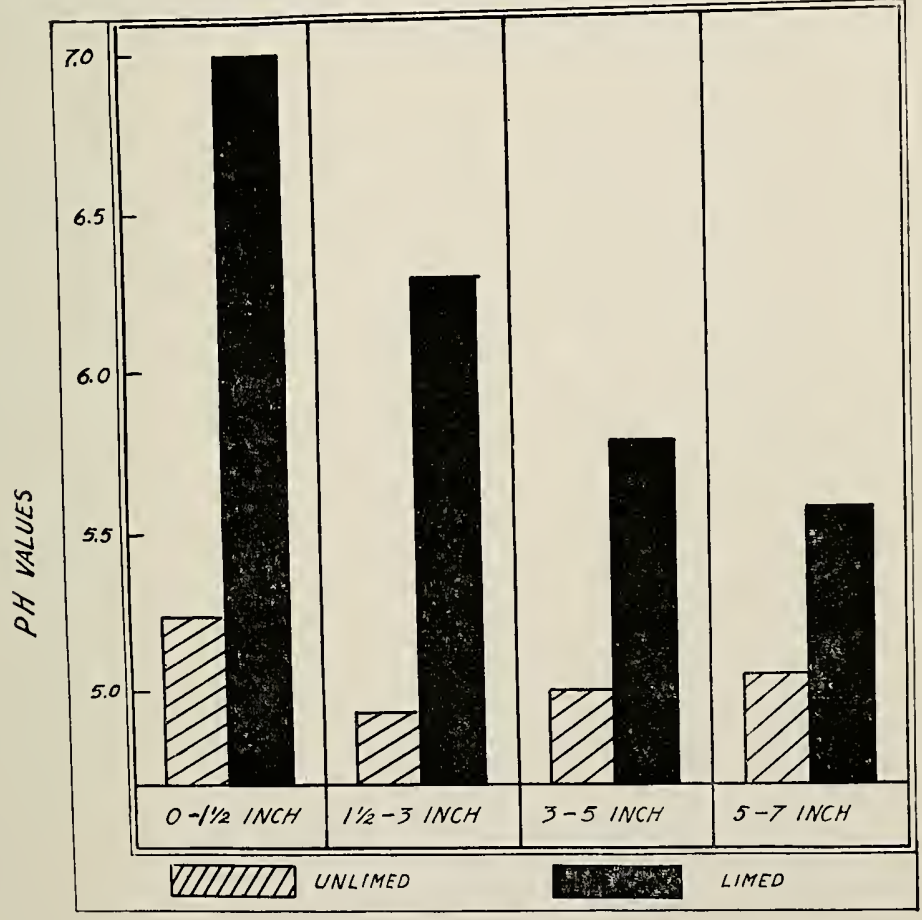

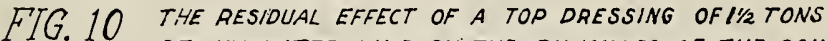

OF HYORATED LIME ON THE PH VALUES. OF THE SOIL AT DIFFERENT DEPTHS THIRTEEN YEARS AFTER APPLICATION. 


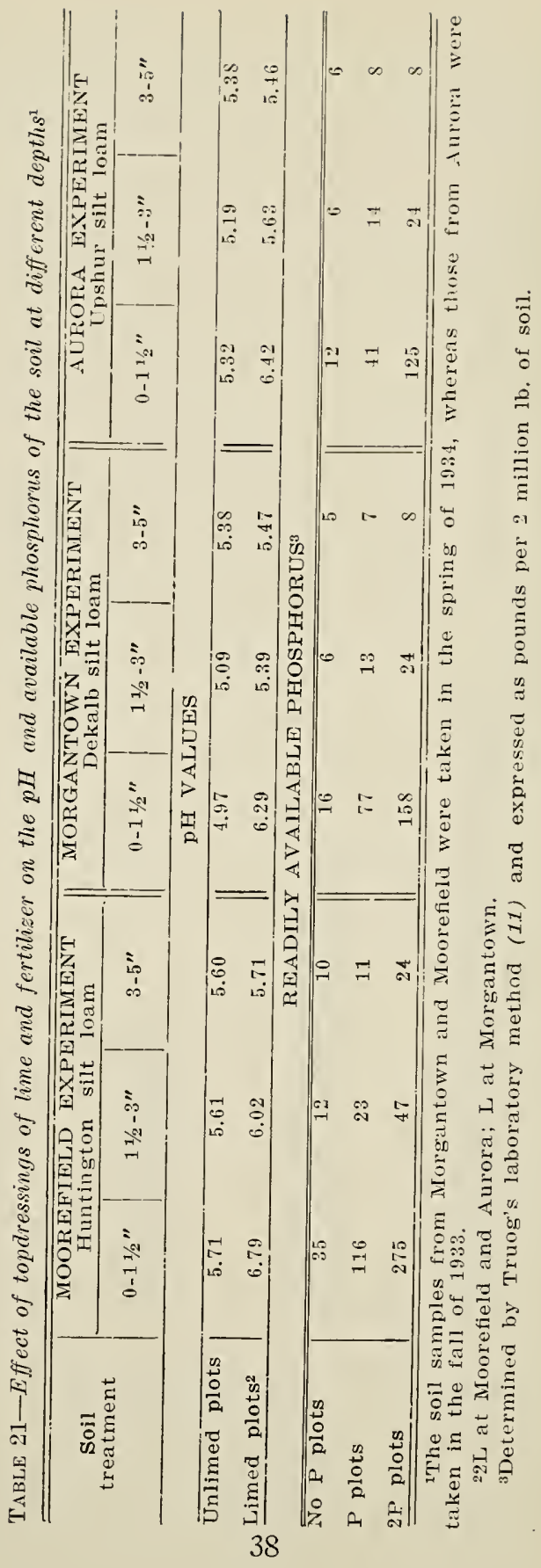


treatment at Morgantown increased the pH of the surface layer from 4.97 to 6.29 . The effect of the lime on the $1 \frac{1}{2}-$-3-in. soil layer, however, was much smaller than in the surface 11/2-in. layer. The penetration of lime below the 3-in. level was negligible. Similarly, the superphosphate reatment resulted in laige increases in readily available phosphorus in the surface layer of soil, but had no significant effect in the 3-5-in. layer. These results are in agreenent with those reported by Brown and Munsell $(1,2)$. It is obvious, therefore, that pasture soils do not lose any ippreciable amount of lime $0 l^{\circ}$ phosphorus through leaching. It should Iso be recognized that much of the lime and phosphorus that is removed yy the plant under grazing conditions is returned to the soil in the manire. Part of the phosphorus added in fertilizers, however, becomes ixed in the soil in an unavailable form.

From these data it is evident that the cost of improving permanent sastures by the use of lime and superphosphate cannot be charged to he benefits obtained during the first few years. The residual effect of the lime may be considerable for more than 20 years. 'This does not nean, of course, that more lime need not be added during the period, out that the amounts needed will be relatively small. Once a good blueyrass and clover sod has been reestablishcd, the cost of maintaining it ihould be low as compared to the initial treatment.

\section{Effect of Lime and Fertilizer on Quality of Herbage}

It is well recognized that grazing animals will do much better on :ome pastures than on others, regardless of the amount of feed available. High yields therefore are not the only considerations in a pasture prorram. As was shown in Tables 5 and 6 , the vegetation of the untreated ind poorly treated plots of these experiments consists mostly of poverty rrass and weeds, whereas that of the plots treated with phosphorus and ime or with a complete fertilizer consists to a considerable extent of Kentueky bluegrass and other desirable species. Not only are bluerrass, white clover, and other desirable species more palatable than most veeds and such grasses as broomsedge and poverty grass, but they have yreater nutritive value ( 8$)$.

The nutritive value of pasture herbage can best be determined by eeding experiments, yet there are certain basic requirements that can

ГABLE 22-Phosphorus, calcium, and protein content of the air-dry herbage from certain plots on the Morgantown and Moorefield experiments ${ }^{1}$

\begin{tabular}{|c|c|c|c|c|c|c|}
\hline \multirow[b]{2}{*}{$\begin{array}{l}\text { Fertilizer and } \\
\text { lime treatment }\end{array}$} & \multicolumn{3}{|c|}{ Morgantown experiment } & \multicolumn{3}{|c|}{ Moorefield experiment } \\
\hline & Phosphorus & $\begin{array}{c}\text { Calcium } \\
\%\end{array}$ & $\begin{array}{c}\text { Protein } \\
\%\end{array}$ & Phosphorus & $\left|\begin{array}{c}\text { Calcium } \\
\%\end{array}\right|$ & $\begin{array}{c}\text { Protein } \\
\%\end{array}$ \\
\hline None & 0.168 & 0.67 & 10.9 & 0.280 & 0.58 & 13.6 \\
\hline $\mathrm{P}-\mathrm{K}-\mathrm{L}$ & $0.27 \mathrm{~S}$ & 0.99 & 14.6 & 0.337 & 0.71 & 14.8 \\
\hline $2 \mathrm{~N}-\mathrm{P}-\mathrm{K}-\mathrm{L}$ & 0.263 & 0.92 & 15.5 & 0.331 & 0.51 & 15.6 \\
\hline $2 \mathrm{~N}-2 \mathrm{P}-\mathrm{K}-\mathrm{L}$ & 0.337 & 0.98 & 16.0 & 0.361 & 0.55 & 16.0 \\
\hline
\end{tabular}

${ }^{1}$ Average of 5 years at Morgantown (4 years for the $2 \mathrm{~N}-2 \mathrm{P}-\mathrm{K}-\mathrm{L}$ treatment) ind 4 years at Moorefield.

All treatments are in quadruplicate. 
be determined by chenieal methods. Henderson and Weakley (3) found that for growing clairy animals, "rations which contain less than 0.35 percent of ealcium or less than 0.20 pereent of phosphorus give rise to a bone which is low in ash and consequently high in moisture and extractable material." For high prodncing dairy cows Il uffuan of al. (1) fomd that even 0.20 pereent phosphorus in the ration is inadecuate.

The average phosphorus, calciun, and protein contents of the herbage from certain plots at Morgantown and at Mocrefield are summarized in Table 22. Herbage from the moreated plots at Morgantown averaged only 0.168 phosphorus, which is below the minimum vahe of 0.20 found to be necessary for growing dairy cattle. The use of liberal amounts of fertilizer doubled the phosphorus content of the herbage. The calcium content of the herbage from the untreated plots averaged 0.67 percent. which appears to be adequate for grazing purposes. A more detailed study (8), however, shows that the high percentage of ealcium in the herbage of the untreated plots is due to the high calcium content of the weeds and that the poor native grasses from these plots contain much less than 0.35 percent calcium. The P-K-L treatment increased the protein content of the herbage from 10.9 to 14.6 , an increase of $3 t$ percent. This increase was due largely to the increase in the amount of white clover in the herbage. Nitrogen fertilization, in addition to P-K-I, gave an additional inerease in the protein content of the herbage. The cffert of nitrogen fertilizers, however, will be discussed more fully in another publication.

At Moorefield, with a more productive soil and a more desirable type of vegetation, the phosphorus content of the herbage from the untreated plots was much higher than at Morgantown, averaging 0.280 percent. There was still a very marked increase, however, from the use of phosphate fertilizer. The ealcium content of the herbage was inereased from 0.58 percent to 0.71 pereent by the P-K-L, treatment, but nitrogen fertilization produced a marked decrease due largely to a decrease in the percentage of elover. Both the P-K-L and the complete fertilizer treatments gave substantial increases in the protein content of the herbage.

\section{Relation Between Yieldo From Clipping and From Grazing}

Another consideration that must be remembered in interpreting the results of pasture fertilizer experiments is that under clipping conditions all the herbage is removed, whereas under grazing a large portion of the fertilizer clements in the herbage is returned to the soil in the manure. The result, as shown from the data obtained at Wardensville and published in detail elsewhere (10), is that the yields from clipped plots gradually decrease over a period of years as compared with those obtained by grazing. Therefore the actual increases in vield of harvested herbage, as shown for the various treatments in Tables 14 to 1.9 , inclusive, are lower than would be obtained under grazing conditions. The percentage increases in yield obtained by clipping with a lawn- 
mower, however, were found to be very similar to those obtained by grazing (10). Thus it appeal's that the percentage increase in yields of elipped plots ean be used in estimating the increased carrying capaeity of the pasture as a result of treatment, provided the carrying eapacity of the untreated pasture is known. It is on this basis that the yields obtained in this investigation will be interpreted.

It is realized that this method of interpreting the results of clipping experiments is subject to certain errors and also that it may not apply to all pastures. In general, however, it is believed that the pereentage inereases in yield determined in this manner would be underestimated rather than overestimated, especially on the poorer soils, where the herbage is largely poverty grass on the untreated plots as compared with lientueky bluegrass and white clover on the iimed and fertilized plots. IIoreover, this method makes no allowance for the residual effect of the fertilizer and lime.

\section{GENERAL CONSIDERATIONS AND INTERPRETATION OF RESULTS}

In evaluating the benefits of a pasture-improvement program, due cousideration must be given to the effect of the program on the farm unit as a whole. If a farmer doubles the carrying capacity of his pasture through the use of lime and fertilizer, he should not overlook the inportance of making the most efficient use of that extra feed. Some farmers might find it most profitable to increase the size of their herd, whereas others would find it more profitable to give major consideration to decreasing the amount spent for supplementary feed. The latier view might also involve a change in the ratio of crop land to pasture. Thus it appears that any monetary interpretation of the results would have only a very general application.

TABLE 23-Summary and interpretation of the yields of forage from the experiment on the Delalb silt loam at Morgantown

\begin{tabular}{|c|c|c|c|c|}
\hline $\begin{array}{c}\text { Plot } \\
\text { treatment }\end{array}$ & $\begin{array}{l}\text { Relative } \\
\text { yields of } \\
\text { clipped } \\
\text { forase }\end{array}$ & $\begin{array}{l}\text { Estimated } \\
\text { calrying } \\
\text { capacity } \\
\text { (Acres per } \\
\text { animal unit) }\end{array}$ & $\begin{array}{c}\text { Estimated } \\
\text { feed value } \\
\text { (Lb. per acre } \\
\text { of alfalfa } \\
\text { hay })^{2}\end{array}$ & \begin{tabular}{|} 
Arerage annual \\
cost per acre \\
of lime and \\
fertilizer \\
(dollars)
\end{tabular} \\
\hline $\begin{array}{l}\text { None } \\
\mathrm{I} . \\
\mathrm{P} \\
\mathrm{P}-\mathrm{L} \\
\mathrm{P}-\mathrm{K}-\mathrm{L} \\
\mathrm{N}-\mathrm{P}-\mathrm{K} \\
\mathrm{N}-\mathrm{P}-\mathrm{K}-\mathrm{L} \\
\mathrm{j} / 2 \mathrm{~N}-\mathrm{P}-\mathrm{K}-\mathrm{L} \\
2 \mathrm{~N}-\mathrm{P}-\mathrm{K}-\mathrm{I} \\
2 \mathrm{~N}-2 \mathrm{P}-\mathrm{K}-\mathrm{I} \\
\mathrm{N}-2 \mathrm{P}-\mathrm{K}-\mathrm{L}\end{array}$ & $\begin{array}{l}100 \\
119 \\
136 \\
164 \\
199 \\
192 \\
236 \\
228 \\
272 \\
288 \\
258\end{array}$ & $\begin{array}{l}5.0 \\
4.2 \\
3.7 \\
3.1 \\
2.5 \\
2.6 \\
2.1 \\
2.2 \\
1.8 \\
1.7 \\
1.9\end{array}$ & $\begin{array}{r}800 \\
950 \\
1080 \\
1290 \\
1600 \\
1540 \\
1910 \\
1820 \\
2220 \\
2350 \\
2100\end{array}$ & $\begin{array}{r}1.03 \\
1.64 \\
2.67 \\
3.33 \\
5.16 \\
6.06 \\
4.70 \\
9.02 \\
10.63 \\
7.67\end{array}$ \\
\hline
\end{tabular}

${ }^{1}$ Assuming that 5 acres per animal unit would be required for the untreated area and that the percentage increases from clipping are the same as would have been obtained by grazing $(7,10)$.

${ }^{2}$ Based on $4000 \mathrm{lb}$. of alfalfa hay per animal unit.

If allowance were made for the residual effects the cost would be nıuch smaller. 
In view of these considerations the eftect of lime and fertilizer treatments will be interpreted in terms of (1) the increase in the estimated earrying eapacity of the pasture. and (2) the feed value of the estimated inerease in terms of alfalfa hay. The lesults of this interpuretation are summarized in Tables 23 to 26 inclusive. (The Wardensville, Spencer, and Palestine experiments were omitted in this summary because the yields are available for only two years.)

On the Morgantown experiment $\$ 3.33$ per acre per rear for lime, superphosphate, and muriate of potash increased the estimated carrying eapacity from 5.0 acres per animal unit to 2.5 acres per animal unit (Table 23).* When converted to alfalfa hay-equivalent this means 800 pounds per acre per year from the unfertilized plots as compared with 1600 pounds from the fertilized plots. In addition, as already shown, the lime and fertilizer will continue to give marked increases in yield for a number of years. At Aurora (Table 24) $\$ 1.6+1$ per rear for superphosphate inereased the calculated carrying eapacity from 4.5 acres per animal unit to 2.4 acres per animal unit. Expressed in alfalfa hayequivalent the increase amounted to 780 pounds per acre per year. The increase from lime and superphosphate at Aurora was not as ceonomical as the increase from superphosphate alone because, as already noted, this pasture did not respond to lime. At Moorefield $\$ 2.65$ for lime and superphosphate gave an estimated inerease of 960 pounds of alfalfa hay.

TABLE 24-Summary and interpretation of the yields of forage from tise crperincut on the Upshur clay loam at Aurora

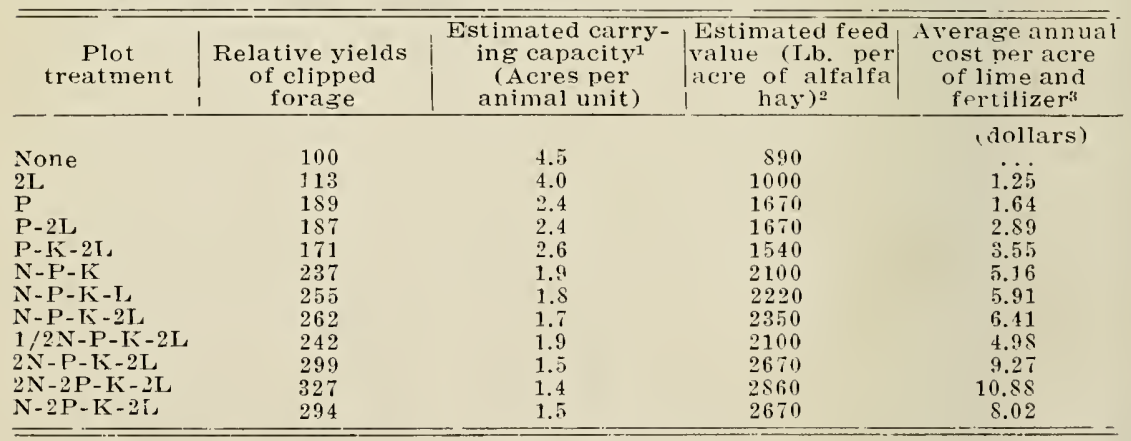

1 Assuming that 4.5 acres per animal unit would be required for the untrezted area and that the percentage increases from clipping ate the same as would have been obtained by grazing $(\gamma, 10)$.

${ }^{2}$ Based on $4000 \mathrm{lb}$. of alfalfa hay per animal unit. smaller.

If allowance were made for the residual effects the cost would be much

*Prices charged for lime and fertilizer were as follows:

Limestone ( $100 \%$ calcium carbonate equivalent) ....\$4.00 per ton

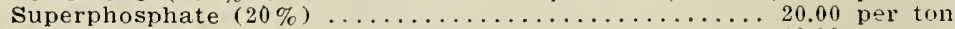

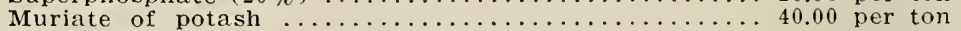

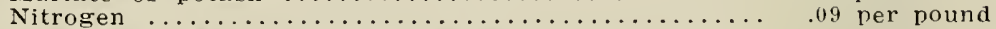

No charge was made for hauling and spreading, but on the other hand no credit was given for the residual effect of the lime and superphosphate. The cost of the lime and fertilizer plus interest at $5 \%$ was divicled into annual payments, the final one coming due in the fall of 1336. 
It is interesting also to note that in some ases complete fertilizer and lime appears to be about as profitable as mineral fertilizer's and lime. l'his is particularly true on the Westmoreland silt loam where, as preriously noted, the response to phosphate fertilizer was low because the lots had little elover, and there was a marked nitrogen deficiency. It hould be recognized, however, that the resirlual effect of nitrogen ferilizer is very small eompared with that of lime and superphosphate, and Iso that the expense of applying nitrogen is greater because it must se applied more frequently. Moreover, it is believed that because of :everal unusually dry seasons during the course of these experiments here has been considerably less elover on the plots than would ordinarily recur in a fertilized pasture. This would result in overestimating the eturns from nitrogen fertilization and underestimating the returns rom lime and superphosphate.

Another important consideration with nitrogen fertilization is whether or not the extra pasture produced ean be effieiently utilized. Jnder average weather conditions the greatest increase in yield from nitrogen fertilization will oceur when the nitrogen is applied in the ipring. When applied at this time it gives the grass an early start and hus may advance the grazing season by a week or ten days. However, เ part of the increases in yield from the spring application of nitrogen will come at the time of peak production of the pastures that do not 'eceive nitrogen fertilizer, and very little if any increases in yield will se obtained during the latter part of the season. Moreover, if a pasture s lightly grazed during May and June, the use of nitrogeli fertilizer in he spring will tend to erowd out white clover and consequently may retually decrease the yield during the latter part of the season. If litrogen fertilizers are used in addition to phosphorus and lime, therecore, more attention needs to be given to good managenent practices.

In view of these considerations it appears that, in general, the most rofitable returns on West Virginia pastures will result from the use of superphosphate and lime. On some soils potash may also be profitable. Nitrogen fertilizer's in addition to lime and superphosphate may give profitable returns, particularly on a slairy farm. provided the uxtra pasture can be utilized efficiently. Nitrogen fertilizer need not be used, however, where there is a good stand of white clover, since the slover will supply nitrogen for the grass.

The farmer who has enough cattle to utilize the luxuriant spring growth in his permanent pasture, particularly when it is fertilized with nitrogen, will, of course, need meadow aftermath, second-girowth alfalfa, or some other temporary pasture to supplement his permanent pasture during part of the season.

\section{SUMIIART AND CONCLUSIONS}

The effect of topdressings of lime and fertilizers on the botanical composition of pasture plsts and on the yield and chemical composition of the clipped herbage was studied on seven permanent pastures in the 
state, situated on different soil iypes. All the pastures exeept one supported a poor type of vegetation and were umproductive.

Topdressings of lime and fertilizer increased the percentage of desirable plants, particularly Kentucky bluegrass and white clover, even though only small amounts of these species were present at the beginning in most of the experiments. At the same time the percentages of weeds, poor native grasses, and bare ground were materially deereased. The first change in the vegetation was usually found to be an inerease in the percentage of white elover. In some of the experiments, where the application of lime and fertilizcrs was followed by a season of favorable weather conditions, large increases in white elover occurred during the first year. In general, however, it tuok at least one rear before the lime and phosphate treatments materially inereased the pereentage of white clover. The increase in the percentage of bluegrass was somewhat more gradual. It was most marked after white clover had beeome well established. Where nitrogen fertilizers were applicd in addition to phosphorus and lime, however, marked increases in the percentage bluegrass often oceurred even before clover was very abundant. Moreover, nitrogen fertilizers when used in addition to phosphorus and lime increased the percentage of bluegrass in the sod, especially in those years when elover was absent or had not been present for several years. The use of nitrogen fertilizers at rates equivalent to 32 and 64 pounds of nitrogen per acre, however, materially reduced the pereentage of elover under the conditions of these experiments.

The inerease in the percentage of white clover from the use of lime and of superphosphate on the various soils was found to be closely related to the acidity and available phosphorus content of the soils. Under average pasture conditions the soil should be limed to a pH value of at least 5.8 and that the available phosphorus eontent of the

TABLE 25-Summary and interpretation of the yields of forage from the experiment on the IIuntington silt loam at Ifooreficld

\begin{tabular}{|c|c|c|c|c|}
\hline $\begin{array}{c}\text { Plot } \\
\text { treatment }\end{array}$ & $\begin{array}{c}\text { Relative yields } \\
\text { of clipped } \\
\text { forage }\end{array}$ & $\mid \begin{array}{c}\text { Estimated carry- } \\
\text { ing capacity }{ }^{1} \\
\text { (Acres per } \\
\text { animal unit) }\end{array}$ & $\begin{array}{c}\text { Estimated feed } \\
\text { value (Lb. } \\
\text { per acre of } \\
\text { alfalfa hay) }\end{array}$ & $\begin{array}{l}\text { Average annual } \\
\text { cost per acre } \\
\text { of linie and } \\
\text { fertilizer }\end{array}$ \\
\hline & & & & (dollars) \\
\hline $\begin{array}{l}\text { None } \\
2 \mathrm{~L}\end{array}$ & 100 & 1.5 & 2670 & $\ddot{7} \dot{S}$ \\
\hline $\begin{array}{l}2 \mathrm{~L} \\
\mathrm{P}\end{array}$ & $\begin{array}{l}107 \\
119\end{array}$ & $\begin{array}{l}1.4 \\
1.3\end{array}$ & $\begin{array}{l}2860 \\
3050\end{array}$ & $0.7 \mathrm{~S}$ \\
\hline $\mathrm{P}-2 \mathrm{~L}$ & $13 \mathrm{~s}$ & 1.1 & & $\begin{array}{l}1.87 \\
2.65\end{array}$ \\
\hline P-IK-2L & 138 & 1.1 & 3640 & 3.40 \\
\hline N-P-K & 157 & 1.0 & 4000 & 5.4 .5 \\
\hline$N-P-K-L$ & 153 & 1.0 & 4000 & 5.88 \\
\hline $\mathrm{N}-\mathrm{P}-\mathrm{K}-2 \mathrm{~L}$ & 160 & 0.9 & 4440 & 6.26 \\
\hline $1 / 2 \mathrm{~N}-\mathrm{P}-\mathrm{K}-2 \mathrm{I}$ & 145 & 1.9 & 4000 & $4 . \$ 3$ \\
\hline $2 \mathrm{~N}-\mathrm{P}-\mathrm{I}-2 \mathrm{~L}$ & 188 & 0.5 & 5000 & 9.12 \\
\hline $2 N-2 P-K-2 L$ & 195 & 0.8 & 5000 & 10.95 \\
\hline $\mathrm{N}-2 \mathrm{P}-\mathrm{K}-2 \mathrm{I}$, & 167 & 0.9 & 4440 & 8.09 \\
\hline
\end{tabular}

${ }^{1}$ Assuming that 1.5 acres per animal unit would be required for the untreated area and that the percentage increases from clippings are the same as would have been obtained by grazing $(\%, 10)$.

3Based on $4000 \mathrm{lb}$. of alfalfa hay per animal unit.

If allowance were made for the residual effects the cost would oe much smaller. 
soil should be at least 20 pounds per $2,000,000$ pourrls of soil if a grood pasture is to be obtained.

The average increase in yields from lime and superphosphate varied from 38 percent on the relatively fertile IIuntington soil to 87 percent on the Upshur elay loam. Where eomplete fertilizer was used in large amounts in addition to lime, the incense in yields was raised to as high as 227 percent on the Upshur clay loam soil.

The increases in yield from the varions treatments were affected not only by the fertility of the soil but also by the season and by the presence of white clover. When elover was present in considerable amounts, large inereases in yield were obtained on all plots from the use of superphosphate and lime, and on the Dekalb soil from potash; but relatively small increases were obtained from the addition of nitrogen fertilizers. When elover was absent, however. the increase yields from nitrogen were sometimes as great if not greater than from lime and superphosphate.

The use of lime and superphosphate materially inereased the protein, the calcium, and particularly the phosphorus content of the herbage. This increase was still evident $4 \frac{1}{2}$ years after the last treatment. The main reason for the higher nutritive value of the herbage of the treated plots is that the vegetation has been changed from one consisting mostly of weeds and poor native grasses to one dominantly of bluegrass, with white clover present in favorable seasons.

Data are presented showing the large residual effect of lime and superphosphate treatments. In an old pasture experiment, where a very acid soil received $11 / 2$ tons of hydrated lime 13 years previously, no lime was needed for good growth of the desirable species. most of the lime still being present in the surface three inches of the soil. On the unlimed plots there was present only 7 percent of desirable species as compared with $40 \%$ on the limed plots. These data empliasize the importance of considering the costs of pasture fertilization and liming as a long-time investment. Althongh the initial cost of improving a depleted pasture may range from $\$ 5$ to $\$ 10$ an acre, it should be remembered that once

TABLE 26-Summary and interpretation of the yields of forage from the experiment on the Westmoreland silt loam at Maidsville

\begin{tabular}{l|c|c|c|c}
\hline \hline $\begin{array}{c}\text { Plot } \\
\text { treatment }\end{array}$ & $\begin{array}{c}\text { Relative yields } \\
\text { of clipped } \\
\text { forage }\end{array}$ & $\begin{array}{c}\text { Estimated carry- } \\
\text { ing capacity } \\
\text { (Acres per } \\
\text { animal unit) }\end{array}$ & $\begin{array}{c}\text { Estimated feed } \\
\text { value (Lb. per } \\
\text { acre of } \\
\text { alfalfa hay) }\end{array}$ & $\begin{array}{c}\text { Average annual } \\
\text { cost per acre } \\
\text { of fertilizer } \\
\text { (dollars) }\end{array}$ \\
\hline None & 100 & 3.0 & 1330 & 1.87 \\
P & 120 & 2.5 & 1600 & 4.73 \\
N-P & 150 & 2.0 & 2000 & 5.48 \\
N-P-K & 156 & 1.9 & 1910 & 4.05 \\
I/2N-P-K & 142 & 2.1 & 1910 & \\
\hline
\end{tabular}

IAsuming that 3.0 acres per animal unit would be required for the untreated area and that the percentage increases from clippings are the same as would have been obtained by grazing $(7,10)$.

2Based on $4000 \mathrm{lb}$. of alfalfa hay per animal unit.

sf allowance were made for the residual effects the cost would be much smallor. 
a good sod is reestablished, the cost of maintaining such a sod will relatively low.

On the basis of these and other studies the effect of liming an fertilization of the pastures was interpretel in terms of the number acres required to pasture one animal and the feed value of the pastu in terms of alfalfa hay. The interpretation, although subject to rertai errors, is believed to be a rery conservative measure of the effect of $t 1$ treatment, particularly in the case of line and sumerphosphate. becalls no allowance could be made for residual effects. Moreover. the metho of interpretation did not take into consideration the superior quality the fertilized pasture.

Even with this conservative method of avaluating the results. th data show large returns from both lime and superphosphate in almo: cvery case. The few exceptions merely emphasize the importance having the so:1 tested before applying lime and fertilizer. It is obrion that no ineri:ises in yield will result from the use of lime if the soil not very arid, and that a soil high in readily available phesphoms wi not respo:ad to superphosphate. Moreover, if a soi! is very deficien in available phosphorus, lime without phosphorus fertilization will ne give a satisfactory return regardless of the degree of acidlity. Similarly. fertilizers will not take the place of lime.

The most profitable returns from the use of lime and fertilizer wi be on soils that are now unproductive but that have a high potenti; productive capacity : i. c., soils that are acid and low in available phos phorus but not droughty, badly eroded, or on very steep slopes. Or'dir arily a combination of lime and superphosphate will give the greates returns for the money invested. It should be recognized, however, thi the profits derived from pasture fertilization will depend not only upo the increases in the yield and quality of the herbage but also upon th value of the products sold. With normal priees for milk. nitroge fertilization in addition to lime and superphosphate may be profitabl on a dairy farm provided the additional feed is utilized efficiently. Th greatest net returns f:om a nitrogen fertilizer will probably be obtaine by applying it early in the spring in order to get early grazinor and thu to decrease tlo s.mount of barn fceding.

\section{LITERATURE CITED}

(1) P::0 i: , B. A., and R. I. Munselu.

I'netration of surface-applied lime and phosplates in the soil of per manent pastures. Storrs Agr. Exp. Sta. Bul. 186. 1933.

$(\because)$

Soil reactions at various depths as influenced by time since applicution placement, and amount of limestone. Soil Sci. Soc. of Amer. 1: 271 275. 1937 .

Henderson, H. O., and C. F. Weaklet, Jr.

The effect of feeding different amounts of ealcium and phosphorus unor the growth and development of dairy animals. W. Ta. Agr. Exp. Sta Bul. 231. 1930. 
(4) Huffian, C. E., and G. E. Taylor.

Depraved appetite in dairy mattle. Mich. Agr. Exp. S.a. Quart. IBul. 8: 174-177. 1926.

(5) Odland, T. E., C. V. Wilson, H. O. Jfenterson, and E. P. Deatrick.

Pasture experiments. W. Va. Agr. Wxp. Sta. Bul. 2235. $19 \% 0$.

(6) Pierre, W. H.

Determination of equivalent acidity and basicity of fertilizers. Ind. and Eng. Chem., anal. ed. 5: 2291-234. 1933.

(7) - et al.

West Virginia Pastures: Type of regetation, earying eapacity, and soil properties. W. Va, Agr. Lxp. Sta. Bul. 280. $19 ; 37$.

(8) and R. R. Robinson.

The ealeium and phosplorus content of pasture herbage and of various pasture speeies as affected by fertilization and liming. Jour. Amer. Soc. Agron. 29: 477-497. 1937.

(9) Robinson, R. R.

Soil properties determining the hotanical composition of pastures in West Virginia. Jour. Agr. Res. 54: 877-\$97. 1937.

(10) - W. H. Pierre, and R. A. Ackerman.

A comparison of grazing and elipping for determining the response of permanent pastures to fertilization. Tour. Amer. Soe. Agron. 29: 349-358. 1937.

(11) Truog, E.

The determination of the readily available phosphorus of soils. Jour. Amer. Soc. Agron. 22: 874-882. 1930. 


\section{CONTENTS}

Introduction

Plan and description of the experiments

Effect of lime and fertilizer on the botanical composition of pastures

Morgantown experiment

Aurora experiment

Moorefield experiment

Maidsville experiment

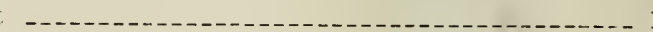

Wardensville experiment

Spencer experiment

Palestine experiment

Relation between the chemical properties of the soil and the response of white clover to lime and superphosphate

Effect of lime and fertilizer on the yields of forage

Relation of white clover to increase in yields

Morgantown experiment

Aurora experiment

Moorefield experiment

Maidsville experiment

Wardensville experiment

Palestine experiment

Factors to be considered in interpreting the yield and other data

Residual effect of lime and fertilizer.

Effect of lime and fertilizer on quality of herbage

Relation between yields from clipping and from grazing

General considerations and interpretation of results

Summary and conclusions

Literature cited 
